\title{
Sox2 Up-regulation and Glial Cell Proliferation Following Degeneration of Spiral Ganglion Neurons in the Adult Mouse Inner Ear
}

\author{
Hainan Lang ${ }^{1}$, Manna Li $^{1}$, Lauren A. Kilpatrick ${ }^{2}$, Juhong Zhu $^{1}$, Devadoss J. Samuvel ${ }^{1}$, Edward L. \\ $\mathrm{KRUG}^{3}$, AND JOHN C. GODDARD ${ }^{4}$ \\ ${ }^{1}$ Department of Pathology and Laboratory Medicine, Medical University of South Carolina, 165 Ashley Avenue, P.O. \\ Box 250908, Charleston, SC 29425, USA \\ ${ }^{2}$ Department of Otolaryngology-Head E Neck Surgery, Medical University of South Carolina, Charleston, SC 29425, USA \\ ${ }^{3}$ Department of Regenerative Medicine $\mathcal{E}$ Cell Biology, Medical University of South Carolina, Charleston, SC 29425, USA \\ ${ }^{4}$ House Ear Institute, Los Angeles, CA 90057, USA
}

Received: 23 July 2010; Accepted: 19 October 2010; Online publication: 9 November 2010

\begin{abstract}
In the present study, glial cell responses to spiral ganglion neuron (SGN) degeneration were evaluated using a murine model of auditory neuropathy. Ouabain, a well-known Na,K-ATPase inhibitor, has been shown to induce SGN degeneration while sparing hair cell function. In addition to selectively removing type I SGNs, ouabain leads to hyperplasia and hypertrophy of glia-like cells in the injured auditory nerves. As the transcription factor Sox2 is predominantly expressed in proliferating and undifferentiated neural precursors during neurogenesis, we sought to examine Sox2 expression patterns following SGN injury by ouabain. Real-time RT-PCR and Western blot analyses of cochlea indicated a significant increase in Sox2 expression by 3 days posttreatment with ouabain. Cells incorporating bromodeoxyuridine (BrdU) and expressing Sox2 were counted in the auditory nerves of control and ouabain-treated ears. The glial phenotype of Sox $2^{+}$ cells was identified by two neural glial markers: S100 and Sox10. The number of Sox $2^{+}$glial cells signifi-
\end{abstract}

Correspondence to: Hainan Lang - Department of Pathology and Laboratory Medicine $\cdot$ Medical University of South Carolina $\cdot 165$ Ashley Avenue, P.O. Box 250908, Charleston, SC 29425, USA. Telephone: +1-843-7922711; fax: +1-843-7920368; email: langh@ musc.edu cantly increased at 3 days post-treatment and reached its maximum level at 7 days post-treatment. Similarly, the number of $\mathrm{BrdU}^{+}$cells increased at 3 and 7 days post-treatment in the injured nerves. Quantitative analysis with dual-immunostaining procedures indicated that about $70 \%$ of $\mathrm{BrdU}^{+}$cells in the injured nerves were $\mathrm{Sox}^{+}$glial cells. These results demonstrate that up-regulation of Sox2 expression is associated with increased cell proliferation in the auditory nerve after injury.

Keywords: primary auditory nerve, glia, proliferation, BrdU, ouabain, neural degeneration

\section{INTRODUCTION}

Spiral ganglion neurons (SGNs) are the primary afferent neurons that comprise the auditory nerve and carry auditory information from the sensory cells of the inner ear to the central nervous system. There are two subpopulations of SGNs: type I and type II. Type I neurons have peripheral processes that synapse inner hair cells, are myelinated, and represent about 95\% of the afferent auditory neurons. The remaining type II neurons are unmyelinated and innervate the outer hair cells. Both type I and type II neurons are biopolar neurons whose cell bodies lie within the Rosenthal's canal and whose central projections form 
the auditory nerve proper within the internal auditory canal. Closely associated with the peripheral and central processes of these neurons are various glial cells, including Schwann cells, satellite cells, and oligodendrocytes. The peripheral portion of the auditory nerve is surrounded by myelinating Schwann cells (for type I SGNs) and non-myelinating Schwann cells (for type II SGNs), while the central portion of the nerve is enveloped by myelin synthesized by Schwann cells in the proximal part and by oligodendrocytes in the distal part. Note that throughout the paper, the term "auditory nerve" without modification refers to the nervous tissue of the eighth nerve extending from synapses with hair cells to the main eighth nerve trunk within the internal auditory canal.

Similar to the glial cells found in other peripheral nerves, SGN-associated glial cells play an important role in supporting normal growth of the auditory nerve. In fact, these glial cells form myelin, maintain homeostasis, and may play a role in many pathological conditions (Romand et al. 1980; Romand and Romand 1990; Hansen et al. 2001; Morris et al. 2006; Hurley et al. 2007; Whitlon et al. 2009; Wang et al. 2010). A previous in vitro study suggests that Schwann cells provide neurotrophic support to the auditory nerve through a reciprocal signaling mechanism (Hansen et al. 2001). In the absence of ErbB2, an essential protein for the development of Schwann cells, there is an associated abnormal innervation of the organ of Corti during inner ear development (Morris et al. 2006). Additionally, a deficiency of fibroblast growth factor receptor signaling in glial cells contributes to the degeneration of SGNs and leads to age-related hearing loss (Wang et al. 2009). Changes of Schwann cell myelinating status and down-regulation of myelin protein zero ( $\mathrm{P} 0)$ expression have also been demonstrated in deafened rat cochleas (Hurley et al. 2007). A spontaneous association of proliferative glial cells with the growth of auditory neurites in a mixed culture of mouse neonatal spiral ganglia suggests a potential role of glial cell activation in promoting the self-repairing processes of auditory nerves (Whitlon et al. 2009). However, little is known about how glial cells of the adult auditory nerve respond to acute cochlear injury and SGN death in vivo. From our prior studies, we found that the application of ouabain to the round window of gerbils yielded reproducible damage to type I SGNs (Schmiedt et al. 2002; Lang et al. 2005). Additionally, we observed hyperplasia of glia-like cells accompanying the up-regulation of basic fibroblast growth factor (FGF2), increased synthesis of glial fibrillary acidic protein (GFAP), and increased matrix metalloproteinase-9 expression as seen in ouabain-injured auditory nerves (Lang et al. 2006a; Jyothi et al. 2010). These findings suggest active roles for glial cells following injury to the auditory nerve.

Activation of glial cells (reactive gliosis) is the hallmark of a lesion to the adult nervous system and has been recognized as such for more than a century. The appropriate reaction of glial cells in response to injury is critical for sealing the damaged site, promoting tissue integrity, restricting inflammation, and preventing further neuronal death (Sofroniew 2005; Silver and Miller 2004). Despite the tendency for gliosis to occur in the setting of neuronal injury, mammalian peripheral nervous tissue has been shown to be capable of regenerating their axons after injury. During this repair process, mature, quiescent Schwann cells revert to more undifferentiated states and become more mitotic. Evidence of such activity has been demonstrated in both adult dorsal root ganglion and sciatic nerve (Clemence et al. 1989; Shinder et al. 1999; Le et al. 2005; Zhang et al. 2008). Investigations of retinal regeneration have also revealed that Müller glia dedifferentiated and proliferated after retinal damage (Fischer and Reh 2001; Karl et al. 2008). However, it is still largely unknown how cochlear glial cells respond to SGN degeneration in the adult cochlea. The goals of this study were to identify specific aspects of glial cell responses to SGN death in vivo and to better understand the roles of glial cells in the injured cochlea and in the self-repair of the adult auditory nerve.

The transcription factor Sox2, a "founder member" of the Sox gene family, is related to the sex-determining gene SRY encoding a high mobility group DNA-binding motif (Avilion et al. 2003). Sox2 is predominantly expressed in proliferating and undifferentiated neural precursors during development and adult neurogenesis in the brain and eye (Ferri et al. 2004; Komitova and Eriksson 2004; Pevny and Nicolis 2010). Sox2 is also required for the determination and formation of the prosensory domains as well as the differentiation of sensory cells and neurons in the developing inner ear (Kiernan et al. 2005; Hume et al. 2007; Dabdoub et al. 2008; Mak et al. 2009; Puligilla et al. 2010). In the adult inner ear, immunocytochemical evidence suggests that Sox2 is involved in the maintenance of supporting cells and a subset of vestibular hair cells (Oesterle et al. 2008), yet little is known about the role of Sox2 in normal and injured adult auditory nerves. The current study examined the expression pattern of Sox2 in the auditory nerve following treatment with ouabain, a known Na,K-ATPase inhibitor. Shortly after SGN degeneration, up-regulation of Sox2 expression appears to be associated with increased glial cell proliferation in the injured auditory nerve ( 3 and 7 days post-treatment). These results suggest that Sox2 plays an important role in regulating the activation of glial cells after injury in the adult auditory nerve. 


\section{MATERIALS AND METHODS}

\section{Animals}

Adult CBA/CaJ mice were bred in-house in a lownoise environment at the Animal Research Facility of the Medical University of South Carolina with original breeding pairs purchased from The Jackson Laboratory (Bar Harbor, ME). All mice received food and water ad libitum and were maintained on a 12-h light/dark cycle. Mice of both genders aged 8-12 weeks weighing 16-25 g were used in the study. The results showed no significant difference in the morphological characteristics of the inner ear between mice aged 8 weeks and those aged 12 weeks. Throughout the paper, the term "young adult mice" applies to all of the 8- to 12-week-old mice. All aspects of the animal research were conducted in accordance with the guidelines of the Institutional Animal Care and Use Committee of the Medical University of South Carolina. Prior to data acquisition, mice were examined for signs of external ear canal and middle ear obstruction. Mice with any symptoms of ear infection were excluded from the study. The mice were administered daily intraperitoneal doses of bromodeoxyuridine (BrdU, $100 \mathrm{mg} / \mathrm{kg}$, Sigma) for 5 days, including the day preceding ouabain treatment, the day of ouabain treatment, and the 3 days following ouabain treatment. BrdU incorporation analysis was processed at 3, 7, 14, and 30 days after ouabain treatment (details in the "Morphological and Immunohistochemical Analysis" below).

\section{Physiological Procedures}

Mice were anesthetized by an intraperitoneal injection of xylazine $(20 \mathrm{mg} / \mathrm{kg})$ and ketamine $(100 \mathrm{mg} / \mathrm{kg})$ and placed in a head holder in a sound isolation room. Young adult $\mathrm{CBA} / \mathrm{CaJ}$ mice before and after ouabain treatment were used for physiological measurements. Auditory brainstem responses (ABRs) were recorded via customized needle electrodes inserted at the vertex $(+)$ and test side mastoid $(-)$, with a ground in the control side leg. The acoustic stimuli were generated using Tucker Davis Technologies equipment III (TuckerDavis Technologies, Gainesville, FL, USA) and a SigGen software package. The calibration was completed using a Knowles microphone in a probe tube clipped to the pinna. The signals were delivered into the mouse ear canal through a 10-mm-long (3- to 5-mm diameter) plastic tube. ABR thresholds, defined as the lowest sound levels at which the response peaks are clearly present as read by the eye from stacked wave forms, were obtained. ABRs were evoked at half octave frequencies from 4 to $45 \mathrm{kHz}$ with 5 -ms duration tone pips with $\cos ^{2}$ rise/fall times of $0.5 \mathrm{~ms}$ delivered at $31 / \mathrm{s}$. Sound levels were reduced in 5-dB steps from 90 to $10 \mathrm{~dB}$ SPL below thresholds. For ABR amplitudes vs. level functions (input/out, I/O function), the wave I peaks were identified by visual inspection at each sound level with the peak-to-peak wave I amplitude computed. At each sound level, 300-500 responses were averaged using an "artifact reject" whereby response waves were discarded when peak-to-peak amplitude exceeded $50 \mathrm{mV}$. Physiological results were analyzed for individual frequencies and then averaged for each of these frequencies from 4.0 to $40 \mathrm{kHz}$.

\section{Surgical Procedures}

Surgical techniques employed to expose the round window of the mouse were modified slightly from a previous description (Lang et al. 2005). Mice were anesthetized as described above. Body temperature was maintained between $36^{\circ} \mathrm{C}$ and $38^{\circ} \mathrm{C}$ using a heating pad. The bulla was exposed through a postauricular approach and a small perforation was created to expose the round window niche. About $5-10 \mu$ l ouabain solution ( $1 \mathrm{mM}$ in normal saline) was applied to the round window, filling the niche completely, using a 26-gauge needle and tuberculin syringe under direct microscopic guidance. The total time of ouabain exposure was $60 \mathrm{~min}$, though every 10 min the ouabain was wicked away and a fresh solution applied. The right ear was the operative ear in most cases, while the left ear served as a control. In addition, four mice received binaural surgery and were allowed to recover for 30 days.

\section{Morphological and Immunohistochemical Analysis}

$\mathrm{CBA} / \mathrm{CaJ}$ young adult mice were used for the following procedures including morphological and immunohistochemical analysis. Ouabain-treated mice showing no ABR threshold shift or a threshold shift $<20 \mathrm{~dB}$ SPL were excluded from further study. For morphological observation, the anesthetized animals $(1,3,7,14$, and 30 days post-treatment) were perfused via cardiac catheter first with $10 \mathrm{ml}$ of normal saline containing $0.1 \%$ sodium nitrite and then $15 \mathrm{ml}$ of a mixture of $4 \%$ paraformaldehyde and $2 \%$ glutaraldehyde in $0.1 \mathrm{M}$ phosphate buffer, $\mathrm{pH}$ 7.4. After removing the stapes and opening the oval and round windows, $0.5 \mathrm{ml}$ of fixative was perfused gently into the scala vestibuli through the oval window. The inner ears were dissected free and immersed in fixative overnight at $4^{\circ} \mathrm{C}$. Decalcification was completed by immersion in about $50 \mathrm{ml}$ of $120 \mathrm{mM}$ solution of ethylenediaminetetraacetic acid (EDTA), $\mathrm{pH} 7.2$, with gentle stirring at room temperature for 23 days with daily changes of the EDTA solution. The tissues were post-fixed with a $1 \%$ osmium tetroxide for $1 \mathrm{~h}$, dehydrated, and embedded in Epon LX 112 resin. 
Semi-thin sections approximately $1 \mu \mathrm{m}$ thick were cut and stained with toluidine blue. Ultra-thin sections were stained with uranyl acetate and lead citrate and examined by electron microscopy as previously described (Lang et al. 2006b).

Micrographs of the semi-thin sections were taken at $\times 63$ magnification on a Zeiss Axio Observer D1 with a digital AxioCam camera. Individual images were opened in Adobe Photoshop CS2, then copied and pasted into a new canvas with sufficient size to reconstruct the cochlea. At high screen magnification, each individual layer was adjusted to a more precise location and locked together using the Photomerge feature of Adobe Photoshop CS2 software.

For immunohistochemistry, the inner ears were prepared following the procedure described above but substituting $4 \%$ paraformaldehyde as fixative, decalcified with EDTA, cryprotected in $30 \%$ sucrose in PBS, and embedded in Tissue-Tek OCT compound (Electron Microscopy Science, FT. Washington, PA). The procedures for observation on surface preparations of the basilar membrane have been described previously (Lang et al. 2006b). The basilar membrane was carefully dissected from the fixed cochlea, pretreated with a mixture of dimethylsulfoxide, $30 \%$ $\mathrm{H}_{2} \mathrm{O}_{2}$, and methanol (1:1:4 by volume) according to the method previously described (Sekerková et al. 2005). For BrdU staining, additional pretreatment for frozen tissue sections was included as follows: the sections were denatured with $2 \mathrm{~N} \mathrm{HCl}$ in $0.05 \%$ Tween-20 in PBS, pH 7.4 for $30 \mathrm{~min}$ at $37^{\circ} \mathrm{C}$, and neutralized in $0.1 \mathrm{M}$ sodium borate, $\mathrm{pH} 8.5$, for $10 \mathrm{~min}$.

Frozen sections or surface preparations of cochlear tissue were incubated overnight at $4^{\circ} \mathrm{C}$ with a primary antibody diluted in PBS. The primary antibodies used in this study were mouse anti-BrdU $(1: 1,000$, B2531, Sigma, Atlanta, GA), goat anti-choline acetyltransferase (ChAT, 1:100, AB144P, Chemicon, Temecula, CA), mouse anti-neurofilament 200 (1:200, clone N52, N0142, Sigma), rabbit anti-peripherin (1:150, AB1530, Chemicon), mouse anti-peripherin (1:200, AB1527, Chemicon), mouse anti-S100ß (1:350, S2532, Sigma), goat anti-Sox2 (1:200, sc17320, Santa Cruz Biotechnology, Santa Cruz, CA), rabbit anti-Sox2 (1:500, AB5603, Chemicon), and goat anti-Sox10 (1:100, sc17342, Santa Cruz, CA).

For double staining protocols, the primary antibodies selected were generated in different species (e.g., one mouse monoclonal antibody with one rabbit or goat polyclonal antibody). Note that the antibodies generated in either host gave the same immunolabeling patterns. Biotinylated secondary antibody binding was detected with FITC-conjugated avidin D (1:150, Vector, Burlingame, CA). Detection of the secondary antigens utilized Texas red-conjugated avidin D (1:150, Vector) for visualization. Nuclei were counterstained with bisbenzimide or propidium iodide (PI) in specimens stained with only one primary antibody. Staining of control sections for all primary antibodies included omission of the primary antibody or substitution with similar dilutions of nonimmune serum of the appropriate species. No regionally specific staining was detected in any of these control experiments.

The mouse monoclonal anti-BrdU was produced by clone BU33 and raised against BrdU incorporated into DNA, or coupled to a protein carrier. It recognized proliferative cells in the nuclei of frozen and paraffin-embedded tissue sections of animals treated with an in vivo administration of BrdU (manufacturer's technical information). In this study, we verified that the antibody does not reveal staining in ouabain-treated auditory nerves without BrdU administration.

ChAT is abundantly expressed in cholinergic neurons in the central nervous system. The goat anti-ChAT was generated against mouse and human ChAT and expected to cross-react with avian, guinea pig, monkey, rat, and opossum. A 70-kDa band and a $74-\mathrm{kDa}$ band were revealed on Western blots using rat forebrain and hypothalamus as well as human placenta lysates (manufacturer's technical information). The antibody has been used to identify cholinergic efferent fibers in the mammalian inner ear in several previous studies (Sobkowicz and Emmerling 1989; Huang et al. 2007). The staining patterns of $\mathrm{ChAT}^{+}$ cholinergic efferent fibers in the auditory nerve were identical to another cholinergic marker, vesicular acetylcholine transporter (Darrow et al. 2007).

The goat polyclonal antibody to Sox2 was raised against a peptide corresponding to C-terminus aa 227-293 of human origin (manufacturer's technical information). Using this antibody, previous studies have shown that Sox2 is expressed in the nuclei of the multipotent progenitor cells in mouse eye (Poché et al. 2008) and in the specific neural progenitor cells in the postnatal hippocampal subventricular zone (Navarro-Quiroga et al. 2006). The rabbit polyclonal antibody to Sox2 was generated against a synthetic peptide from human Sox2 (Acc\# P448431, manufacturer's technical information). Both antibodies reveal similar staining patterns in the mouse inner ear. Previous immunocytochemistry studies demonstrated that Sox2 is highly expressed in all prosensory and sensory epithelia of developing mouse inner ear (Dabdoub et al. 2008; Mak et al. 2009), the nuclei of the supporting cells in both auditory and vestibular organs of adult mouse ear (Oesterle et al. 2008), and in the nuclei of Schwann cells in the developing chicken cochleovestibular ganglion (Neves et al. 2007). 
The goat polyclonal antibody to Sox10 was raised against the N-terminal sequences of human Sox10 (1-50 amino acid, manufacturer's technical information). Western blot analysis in 293T whole cell lysates revealed a single band at $38 \mathrm{kDa}$ (manufacturer's technical information). Here, this antibody stained a pattern of cellular morphology and distribution in the mouse auditory nerve identical to that reported previously (Puligilla et al. 2010).

The mouse monoclonal antibody to neurofilament 200 (phosphorylated and non-phosphorylated, clone N52) reacts with the neurofilament of molecular weight $200 \mathrm{kDa}$ in rat spinal cord extracts (manufacturer's technical information). When tested by immunoblotting on pig neurofilament polypeptides, the antibody reacts with an epitope in the tail domain of neurofilament 200, also referred to as the H-subunit, which is present on both the phosphorylated and nonphosphorylated forms of this polypeptide. The staining patterns with neurofilament 200 in the mouse auditory nerve here were similar to those in previous reports (Adamson et al. 2002a, b; Wise et al. 2005; Lang et al. 2006b, 2008).

Peripherin is a 56 - to $58-\mathrm{kDa}$ class III intermediate filament protein expressed extensively in the peripheral nervous system. Both the mouse monoclonal and the rabbit polyclonal anti-peripherin antibodies were raised against the electrophoretically pure trp-Eperipherin fusion protein purified from bacterial inclusion bodies containing all but the four $\mathrm{N}$ terminal amino acids of rat peripherin (manufacturer's technical information). Rabbit anti-peripherin reacts cleanly with an $\sim 57-\mathrm{kDa}$ band from rat brain homogenates and does not recognize vimentin, GFAP, $\alpha$-internexin, or any of the neurofilament subunits (manufacturer's technical information). Both antibodies are used as markers for type II SGNs in the rodent inner ear and reveal similar staining patterns (Reid et al. 2004; Lang et al. 2005).

The mouse monoclonal antibody anti-S100 $\beta$ was generated against purified bovine brain $\mathrm{S} 100 \beta$ (Sigma; catalog no. S2532, lot no. 069K4809). This antibody recognizes an epitope located on the $\beta$ chain, but not on the $\alpha$-chain of S-100 (manufacturer's technical information). It is reactive in dot blots with denatured-reduced preparations of $S 100 \beta$ and in immunohistochemical staining with brain tissues (manufacturer's technical information; Komitova et al. 2005).

The procedures for observation of cochlear hair cells on surface preparations of the basilar membrane have been described previously (Ding et al. 2001). The basilar membrane was stained with FITC-labeled phalloidin $(1 \mu \mathrm{g} / \mathrm{ml}$ in PBS for $20 \mathrm{~min})$ to label filamentous actin and with PI $(1 \mu \mathrm{g} / \mathrm{ml}$ in PBS for $10 \mathrm{~min}$ ) to label nuclei. Hair cells were identified by the presence of the actin-rich hair bundles, the actin belt that rings the apical surface of the cell, and an intact nucleus.

Quantitative analysis of NF200-, peripherin-, BrdU-, and Sox2-expressing cells was performed using cochleas from four to six young adult mice of each group. Cell count data were collected from five to six $15-\mu \mathrm{m}$ midmodiolar frozen sections per cochlea. The sample regions were selected depending on the countable areas of the sections and ranged from 10,800 to $24,800 \mu \mathrm{m}^{2}$ in Rosenthal's canal and from 1,050 to $6,140 \mu \mathrm{m}^{2}$ in the osseous spiral lamina. For cell counts in the osseous spiral lamina regions, measured boundaries were made from the distal site near the habenular opening to a proximal site near the spiral ganglia between the scala tympani and scala vestibuli margins. The values of the sampling area and numbers of NF200-, peripherin-, BrdU-, and Sox2-expressing cells as well as Hoechst-stained (bisbenzimide ${ }^{+}$) nuclei were determined and collected using the Automatic Measurement Feature of AxioVison 4.8 software (Carl Zeiss Inc., Jena, Germany). The sections used for counting were at least $30 \mu \mathrm{m}$ apart (e.g., cell counting was performed on one in every three serial sections). Confirmation of double-labeling Sox2 with BrdU was performed by focusing through the full height of the section (Fig. 12D).

The sections were examined either with a Zeiss Axio Observer or a Zeiss LSM5 Pascal confocal microscope (Carl Zeiss Inc.). The captured images were processed using Image Pro Plus software (Media Cybernetics, MD), AxioVison 4.8 (Carl Zeiss Inc.) and Zeiss LSM Image Browser version 2.0.70 (Carl Zeiss Inc.). Adobe Photoshop CS2 was employed to adjust brightness, contrast, and sharpness of images with identical setting for all panels. Alterations were not performed on images used for quantitative purposes.

\section{Correction for Cell Profile Counts}

Because of the heterogeneity of proliferative cells in the auditory nerve, simple profile-based counts can result in a substantial counting bias. With this cell size variation in mind, Abercromie correction factors were applied to cell counts for BrdU-stained nuclei (Guillery 2002). The correction factor was determined by dividing the section thickness $(15 \mu \mathrm{m})$ by the sum of the section thickness and the average diameter (height) of the neuronal nucleus: $T / T+H$, where $T$ is section thickness and $H$ is the average nuclear height. The average cell diameter was determined separately for each group by measuring the diameter of 20 cells in mid-modiolar sections of Rosenthal's canal randomly selected from the basal, middle, and apical turns. The calculated correction factors for $\mathrm{BrdU}^{+}$cells in apical, middle, and basal 
turns were $0.69,0.70$, and 0.67 for controls, 0.67 , 0.68 , and 0.65 for 3 days post-treatment, $0.68,0.69$, and 0.68 for 7 days post-treatment, $0.69,0.68$, and 0.68 for 14 days post-treatment, and $0.68,0.70$, and 0.67 for 30 days post-treatment. The average cell counts were multiplied by the appropriate correction factor to determine the density of $\mathrm{BrdU}^{+}$cells in each group.

\section{Protein Isolation and Western Blot Analysis}

Ouabain-treated mice were used only if their ABR threshold shifts were more than $20 \mathrm{~dB}$. Inner ear tissues were carefully dissected from the temporal bones of control, 3 days post- and 7 days posttreatment mouse ears (three experiments per group and two isolated auditory nerve fractions per experiment). After removing the cochlear lateral wall and the organ of Corti, the auditory nerve was separated from the vestibular branch of the VIII nerve at inferior aspect of the internal acoustic meatus. The isolated auditory nerve included spiral ganglia within Rosenthal's canal, peripheral elements of nerve fibers within the osseous spiral lamina and modiolus, and the central portion of the nerve fibers within the modiolus. The isolated specimens were extracted in cold lysis buffer (Cell Signaling, Danvers, MA). Protein lysates were boiled for $5 \mathrm{~min}$, subjected to $6-18 \%$ gradient SDS-PAGE $(30 \mu \mathrm{g}$ protein/lane in protein loading buffer), and electro-transferred onto an Immune-Blot PVDF membrane (Bio-RaD, Hercules, CA). Membranes were blocked with BSA/TBST [5\% BSA/Tris-buffered (50 mM HCl-Tris, pH 7.5), $150 \mathrm{mM} \mathrm{NaCl}, 0.02 \%$ Tween-20] for $2 \mathrm{~h}$ then incubated with primary antibodies for $3 \mathrm{~h}$. The blots were washed three times (10 min each) with TBST. To detect the antigen complexes, membranes were incubated with alkaline phosphatase-conjugated secondary antibody (1:6,000, Promega, Madison, WI) for $2 \mathrm{~h}$, rinsed several times with TBST, then incubated with BCIP/ NBT (5-bromo-4-chloro-3-indolyl phosphate disodium salt)/nitrotetrazolium blue chloride, Sigma).

\section{RNA Isolation and Real-Time RT-PCR Processing}

Following treatment with ouabain, mice were allowed to recover for $1,3,7,14$, or 30 days (three to five experiments per group and two isolated auditory nerves per experiment). Both control (left ear) and treatment (right ear) cochleas were harvested using micro-instruments cleaned with RNAse Zap (Qiagen Inc., USA). Microdissection was performed in $3 \mathrm{ml}$ of RNAlater solution (Qiagen Inc., USA). The procedure for microdissection of the auditory nerve was the same as described above. The isolated nerve specimens were stored in RNAse-free microcentrifuge tubes containing $300 \mu$ of RNAlater solution and kept at $4^{\circ} \mathrm{C}$. Total RNA of spiral ganglia was subsequently isolated using the protocol from the RNeasy ${ }^{\circledR}$ Micro Handbook (Qiagen Inc., Germantown, MD).

The total RNA from the treatment and control specimens were subjected to RT-PCR according to protocol from the QuantiTect@ Reverse Transcription Handbook (Qiagen, Germantown, MD). The genomic DNAs in RNA samples isolated from treatment and control cochleas were eliminated by incubating with gDNA Wipeout Buffer for $2 \mathrm{~min}$ at $42^{\circ} \mathrm{C}$. The subsequent reactions utilized Quantiscript Reverse Transcriptase, RT buffer, and RT Primer Mix (Qiagen, Germantown, MD). A reaction volume of $20 \mu \mathrm{l}$ was used followed by a reverse transcription step of $15 \mathrm{~min}$ at $42^{\circ} \mathrm{C}$ and a reverse transcription inactivation step for $3 \mathrm{~min}$ at $95^{\circ} \mathrm{C}$. Quantitative PCR analysis was performed using the SYBR ${ }^{\circledR}$ Green Master Mix Kit (Applied Biosystems, Foster City, CA) and RNase-free 96-well PCR plates. Forward and reverse primers (Qiagen Sciences, Inc, Germantown, MD) for genes for the following proteins were used in the quantitative PCR experiments: 18S (QT01036875, Qiagen Sciences, Inc.), Sox2 (QT00249347, Qiagen, Germantown, MD), and Hes5 (10,336,022, Invitrogen, Carlsbad, CA). In order to assess the precision of the quantitative PCR results, three reactions were performed for each cDNA sample and primer set. Positive and negative controls were also run in triplicate. The thermal cycling parameters were as follows: incubation at $50^{\circ} \mathrm{C}$ for $2 \mathrm{~min}$, followed by activation at $95^{\circ} \mathrm{C}$ for $10 \mathrm{~min}$, followed by 40 cycles of $95^{\circ} \mathrm{C}$ for $15 \mathrm{~s}$ (denaturation) and $60^{\circ} \mathrm{C}$ for $1 \mathrm{~min}$ (anneal). Each sample showed a particular threshold cycle $(\mathrm{Ct})$ value in amplification, which is representative of the relative abundance of the gene in the sample RNA. The Ct value of each sample in the examined gene is normalized with the value of the endogenous control gene, 18S. The relative fold change in gene expression was obtained by comparing Ct data of ouabain-treated ears to that of controls.

\section{Data Analysis}

Unless otherwise specified, all data in the figures are presented as mean \pm SEM. Data for the ABR thresholds, ABR I/O functions, the density of $\mathrm{NF}$ $200^{+}$, peripheral ${ }^{+}$, bisbenzimide ${ }^{+}, \operatorname{Sox}^{+}, \mathrm{BrdU}^{+}$, and $\mathrm{Sox}^{+} / \mathrm{BrdU}^{+}$, as well as the fold changes of Sox2 and Hes5 mRNA, were analyzed by one- and twoway ANOVA or two-tailed, unpaired $t$ test (SPSS, Chicago, IL). A value of $p<0.05$ was considered to be statistically significant. Control samples were the untreated ear from the same animal unless otherwise indicated. 


\section{RESULTS}

Hearing Loss and Type I SGN Degeneration after Ouabain Exposure

Ouabain applied to the round window of young adult $\mathrm{CBA} / \mathrm{CaJ}$ mice induced a severe hearing loss and rapid degeneration of SGNs within a few days (Figs. 1 and 2). ABR wave I thresholds were markedly elevated across all frequencies 1-3 days post-treatment (Fig. 1A-D). ABR responses were absent at most frequencies in mice 7 days or more days after ouabain exposure (Fig. 1A, D). To avoid crossover hearing from the left ear, four mice received bilateral surgery. One month after ouabain exposure, no ABR responses were indicated in any of the eight treated cochleas (Fig. 1D).

ABR wave I amplitude I/O functions have been used as an efficient assay for assessing the gross activity of mouse primary auditory nerve (Jyothi et al. 2010). Figure 1B, $\mathrm{C}$ shows that the maximum amplitudes and slopes of the $\mathrm{I} / \mathrm{O}$ function curves in 1 day postexposed ears were reduced significantly at 8 and $16 \mathrm{kHz}$ compared to control ears (ANOVA, $p<0.05$ ). These results indicate a quick and significant loss of peripheral auditory nerve activity after ouabain exposure in CBA mice, as reported previously in gerbils (Schmiedt et al. 2002; Lang et al. 2005; Corrales et al. 2006). In this study, 144 mice were treated with ouabain. About 9\% ( $n=13$ mice) of ouabain-treated mice showed no ABR threshold shifts or had an ABR shifts that were $<20 \mathrm{~dB}$ SPL by 3 days after ouabain treatment in subsequent tests. These mice were excluded from further morphological, immunohistochemical, and gene and protein expression analysis.

There are two subpopulations of afferent neurons in the spiral ganglia of mouse cochleas, each with their own morphological and electrophysiological characteristics (Jagger and Housley 2003; Reid et al. 2004; Weisz et al. 2009). The first are large type I neurons (Fig. 2A, B) with peripheral process synapsing on inner hair cells. Type I neurons are myelinated and represent approximately $90-95 \%$ of all spiral ganglion neurons. The remaining small type II neurons are unmyelinated and innervate the outer hair cells. Ultrastructural examination revealed apoptotic bodies in most type I spiral ganglion cells in the basal turns 1 day after ouabain treatment (Fig. 2C, D). The apoptotic-like cell death of the type I SGNs was mainly present at 1 and 3 days post-treatment. In contrast, the apoptotic-like degeneration was never seen in type II neurons in any of the ouabain-treated mice.

NF 200 is a well-characterized neural marker for both type I and type II SGNs (Fig. 2G; Berglund and Ryugo 1991; Adamson et al. 2002a, b; Wise et al.
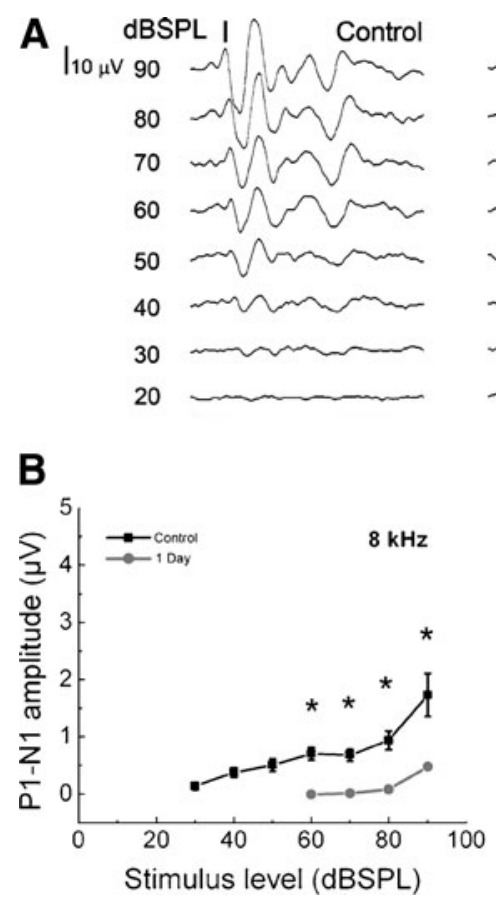

FIG. 1. Hearing loss in ouabain-treated young adult CBA/Cal mice. A ABRs to clicks were recorded at 1, 3, and 7 days after ouabain exposure. B, C ABR amplitude input/output functions at 8 and $16 \mathrm{kHz}$ before and 1 day after ouabain exposure. Note the reduced amplitudes at high stimulus levels when compared with the control and the absence of responses at low levels
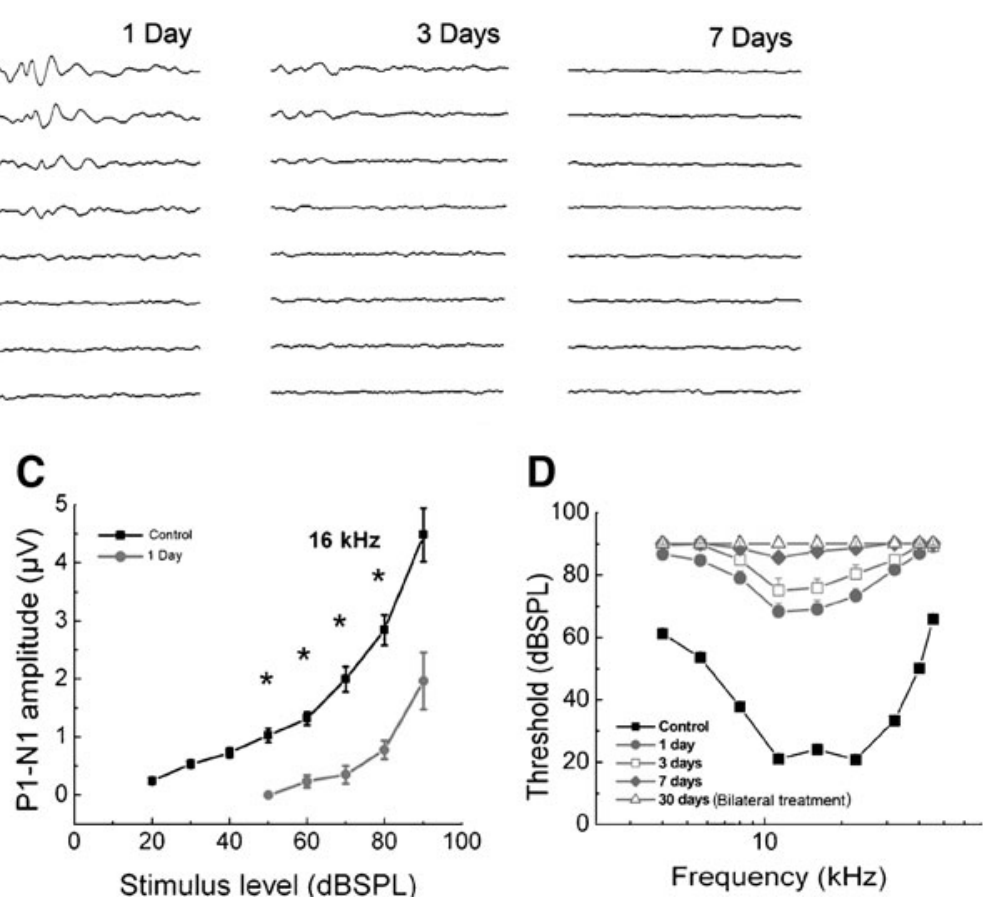

$(n=10)$. D Mean ABR thresholds before and after treatment. One day after ouabain treatment, ABR thresholds were markedly increased at all tested frequencies $(n=28)$. ABR thresholds continued to increase at 3 days $(n=18)$ and 7 days $(n=13)$. No $\mathrm{ABR}$ responses were detected at most tested frequencies 30 days $(n=8)$ after treatment. 

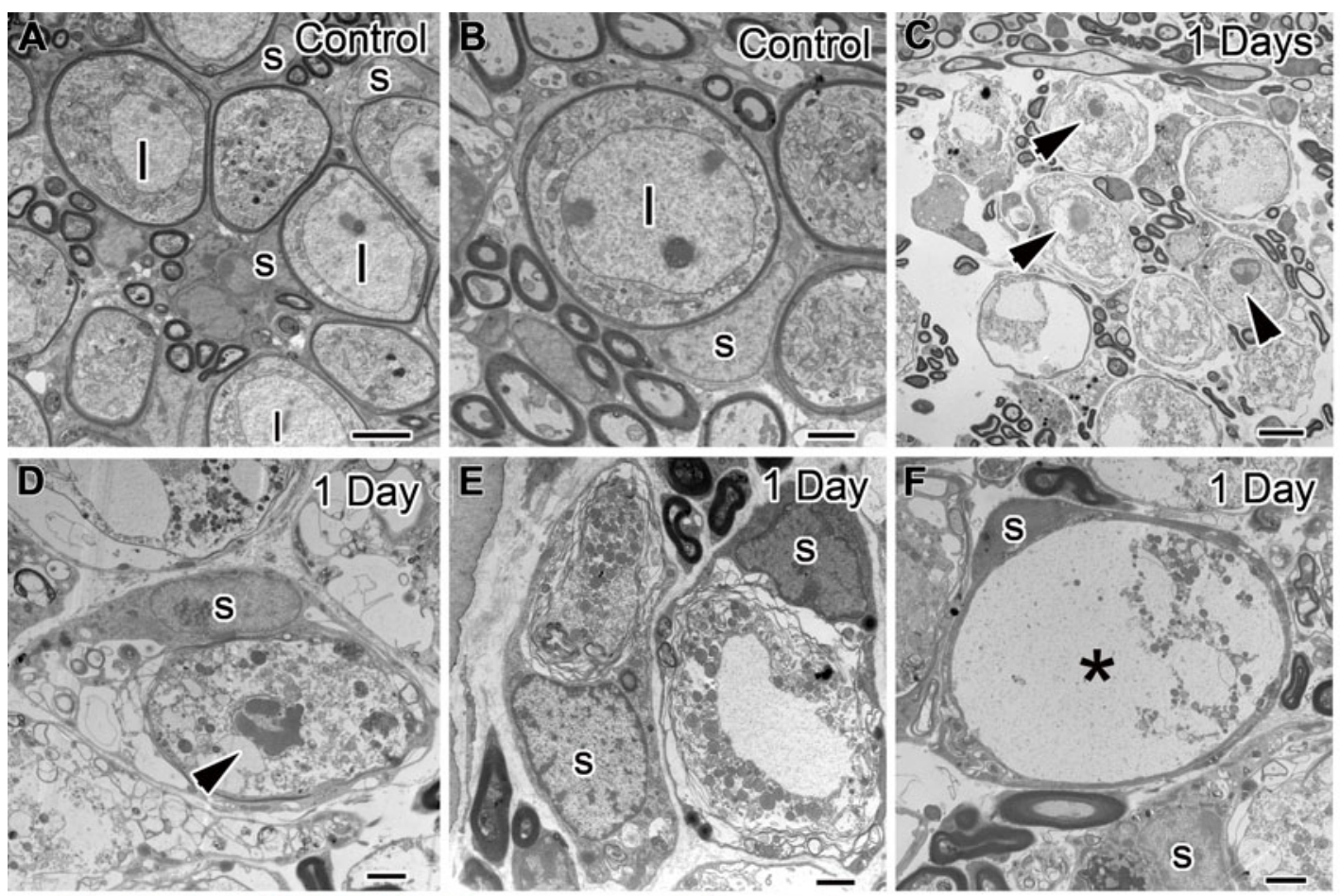
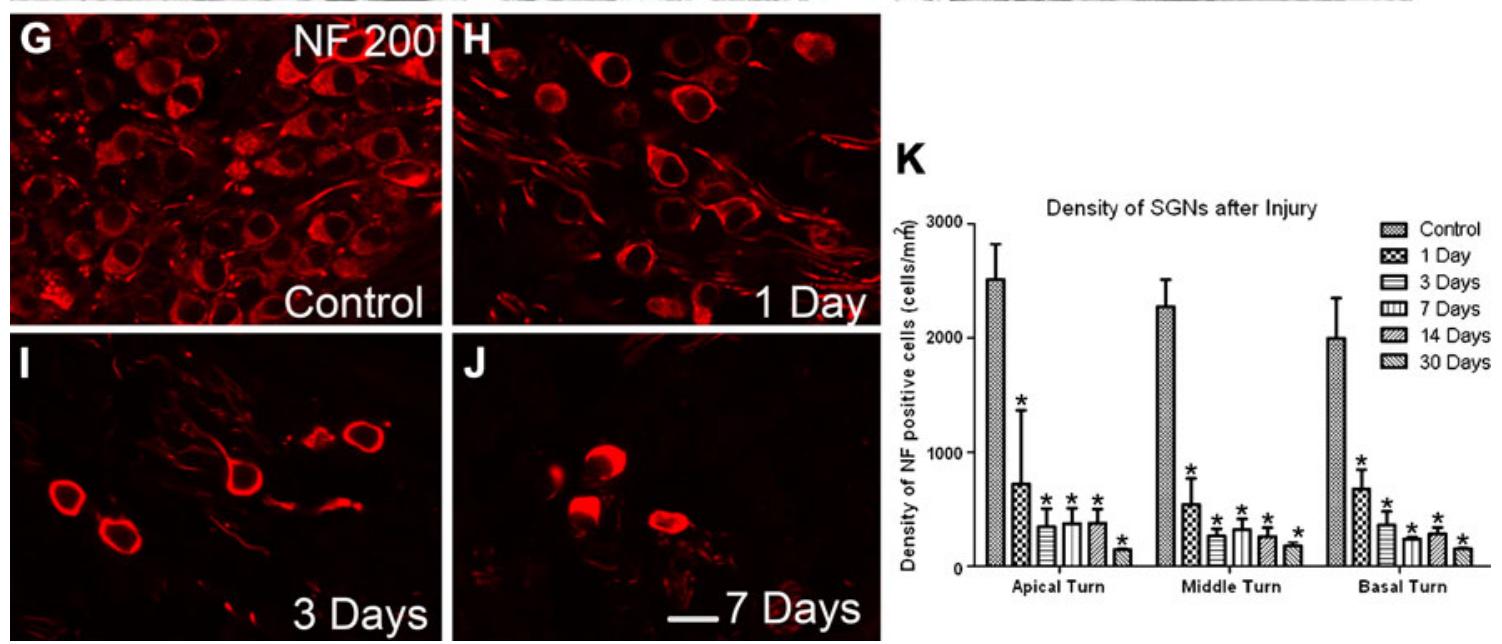

FIG. 2. Type I SGN degeneration after ouabain treatment. A, B SGNs in the middle turn of a young adult CBA/Cal mouse. The perikarya of type I (I) neurons are surrounded by myelinating Schwann cells (s). C, D Apoptotic-like degeneration (arrowheads) appear in the auditory nerve from the basal turn of a mouse 1 day after ouabain treatment. E, F Schwann cells enclose portions of degenerated SGN cytoplasm or the debris of a vanished SGN

2005). To quantify the degree of survival of SGNs, the density of SGNs was counted in control, 1, 3, 7, 14, and 30-day post-treated cochleas. As shown in Figure $2 \mathrm{G}-\mathrm{K}$, there was a significant decline in SGN density in all three turns after ouabain treatment compared to those of controls (ANOVA, $p<0.01$ ). The surviving SGNs in the apical, middle, and basal turns were about $28 \%, 23 \%$, and $33 \%$ of the controls for 1 day post-treatment ears; $13 \%, 12 \%$, and $17 \%$ for 3 days post-treatment; $14 \%, 14 \%$, and $11 \%$ for 7 days post-treatment ears; $14 \%, 11 \%$, and $14 \%$ for 14 days (asterisk). G SGNs stained positive for NF 200 (red) in the basal turn of normal mouse ear. $\mathbf{H}$, I Many NF $200^{+}$cells are missing in the basal turns of the mice 1 and 3 days post-treatment. J Only a few neurons survived in the basal turn of a mouse 7 days post-treatment. K Mean density of NF $200^{+}$SGNs in the apical, middle, and basal turns from control, 1-, 3-, 7-, 14-, and 30-day post-treated ears. Scale bars, $2 \mu \mathrm{m}$ in A, B, D-F; $5 \mu \mathrm{m}$ in C; $15 \mu \mathrm{m}$ in J (applies to G-J).

post-treatment ears; and $5.7 \%, 7.8 \%$, and $7.6 \%$ for 30 days post-treatment ears.

Survival of Type II SGNs, Cholinergic Efferent Fibers, and Sensory Hair Cells

Ultrastructural examination revealed that most type II SGNs were relatively intact in ouabain-treated ears (Fig. 3A-C). Minor pathological changes were seen in these neurons, including small vacuole formation in the cytoplasm and delamination of perikaryon from 

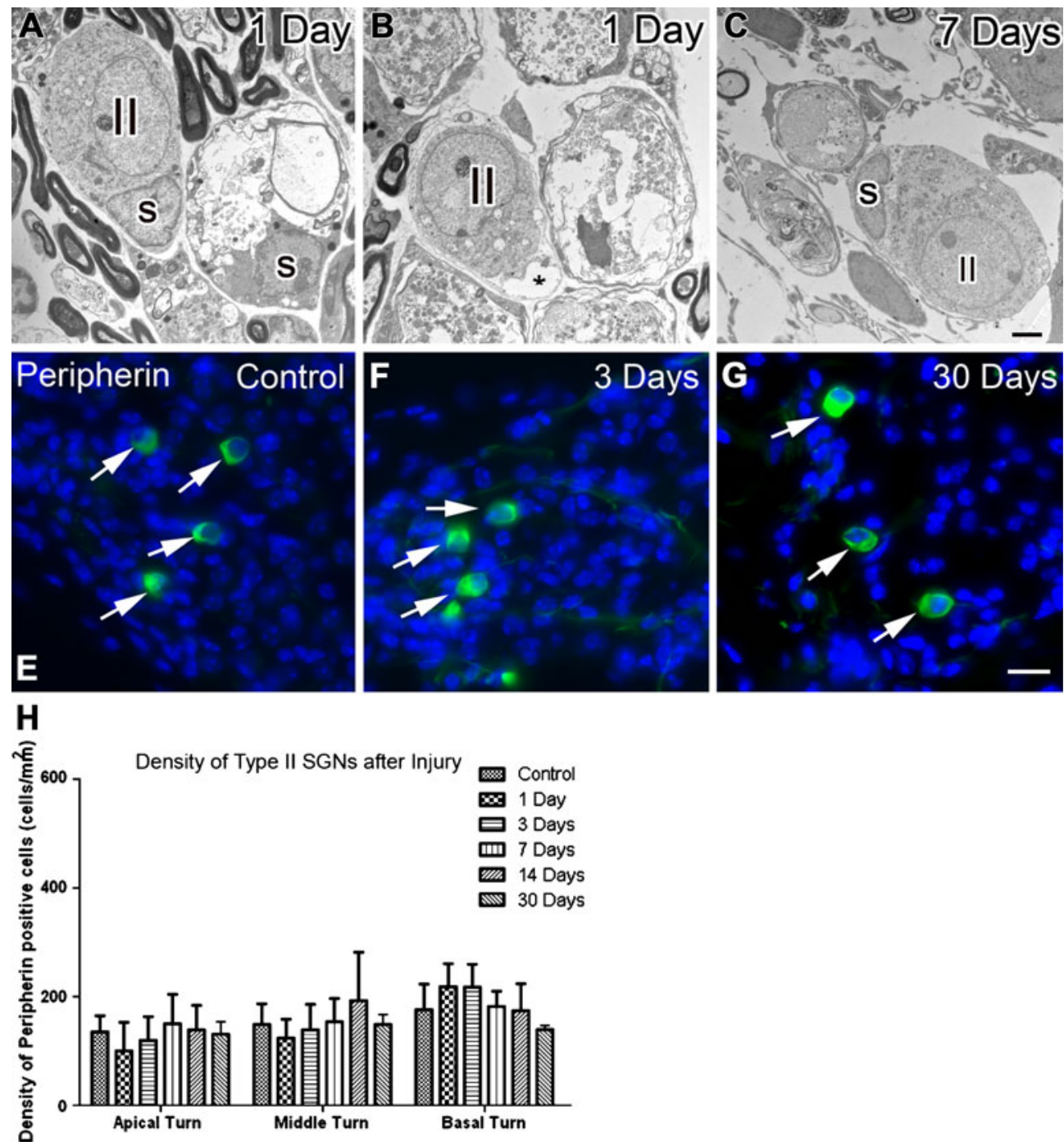

FIG. 3. Type II SGNs survived after ouabain treatment. A A relatively normal-looking type II neuron is present in the apical turn of a mouse 1 day post-treatment. A "homeless" myelinating Schwann cell appears on the right side, indicating a missing type I SGN. B A type II SGN has separated from its non-myelinating Schwann cell sheath (asterisk) in the apical turn of another mouse ( 1 day posttreatment). C Another type II SGN enclosed by a non-myelinating

Schwann cell $(s)$ is present in the middle turn of a mouse 7 days posttreatment. E-G Peripherin ${ }^{+}$type II SGNs (green, arrows) in the apical turns of control, 3-, and 30-day post-treated ears. Nuclei were counterstained with bisbenzimide (b/ue). H Mean density of peripherin $^{+}$type II SGNs in the apical, middle, and basal turns of control, 1-, 3-, 7-, 14-, and 30-day post-treated ears. Scale bars, $2 \mu \mathrm{m}$ in $\mathbf{C}$ (applies to $\mathbf{A}-\mathbf{C}$ ); $15 \mu \mathrm{m}$ in $\mathbf{G}$ (applies to $\mathbf{E}-\mathbf{G}$ ).

the process of a non-myelinating Schwann cell (Fig. 3B). Peripherin, an intermediate filament protein, is a commonly used marker for type II SGNs (Hafidi 1998; Reid et al. 2004). To further examine whether ouabain-induced neural degeneration occurred only in type I neurons, peripherin-expressing cells were counted in control and ouabain-treated mice (Fig. 3E-H) . No significant decrease of the peripherin ${ }^{+}$ cells was seen in any of the ouabain-treated groups (ANOVA, $p>0.05$ ).

Confocal images of surface preparations of cochleas stained with NF-200 and ChAT allow visualization of the afferent and efferent auditory fibers (Fig. 4A-H). Thirty days after ouabain treatment, most radial afferent NF $200^{+}$fibers (beneath inner hair cells) had disappeared, but those NF $200^{+} / \mathrm{ChAT}^{-}$afferent fibers below outer hair cells (type II fibers) still can be seen clearly in the apical turn (Fig. 4A) and occasionally seen in the middle and basal turns (Fig. 4D, H). The $\mathrm{ChAT}^{+}$efferent fibers innervating OHCs were present in the treated ears (Fig. 4F, H). There were numerous $\mathrm{ChAT}^{+}$clusters in the IHC region $\left(^{*}\right)$, yet it seems unlikely that these $\mathrm{ChAT}^{+}$clusters were true efferent terminal endings as all of their targeted afferent fibers were in fact absent (Fig. 4H). In addition, surface preparations stained with phalloidin showed that actin-positive stereocilia bundles on IHCs and OHCs were relatively normal (Fig. 5A-C). 

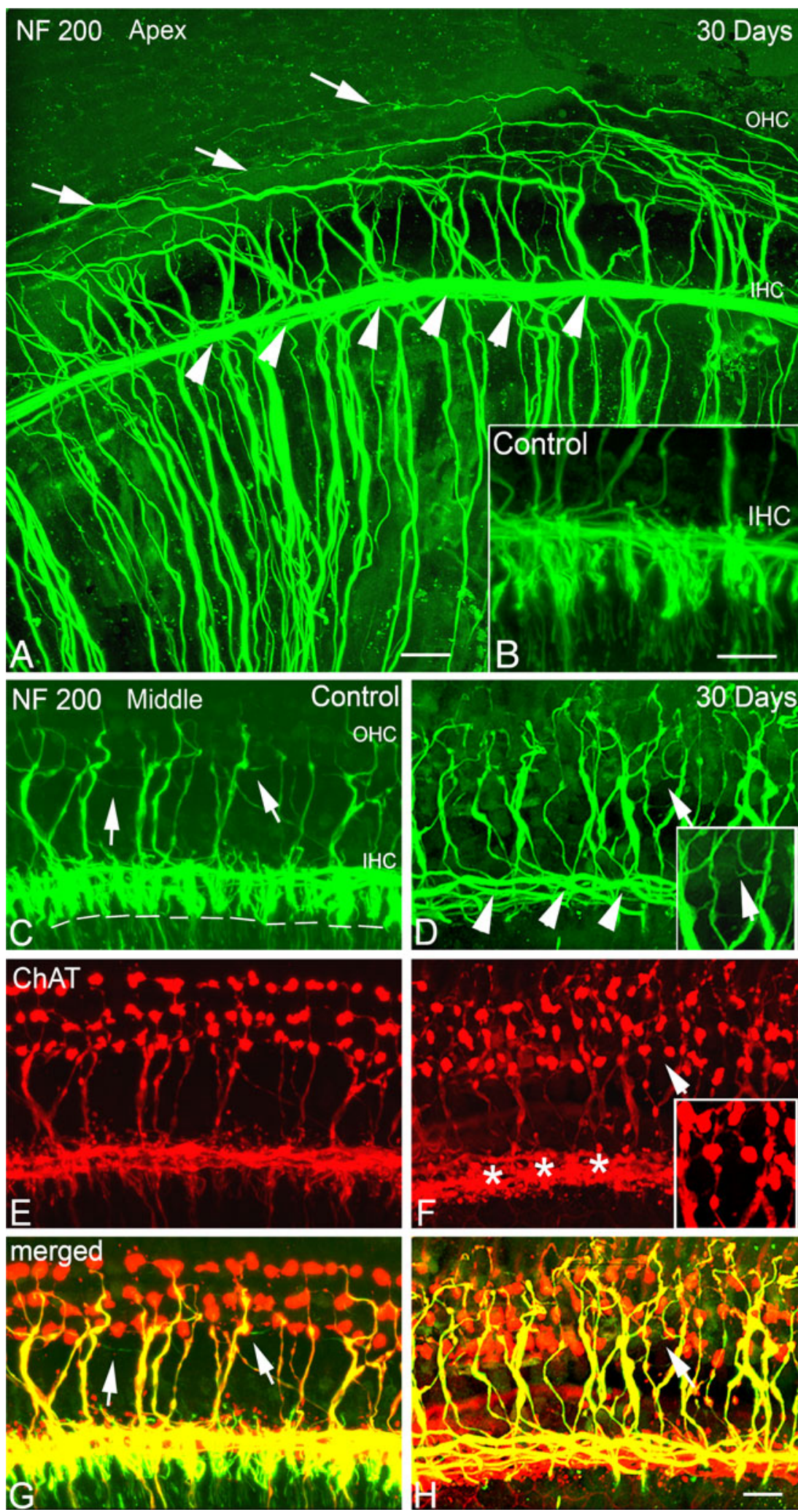

FIG. 4. Cochlear afferent and efferent innervation patterns after ouabain treatment. A, B Loss of NF $200^{+}$afferent fibers innervating IHCs (arrowheads) in the apical turn of a mouse at 30 days posttreatment. Surface preparation from the apical turns of a mouse 30 days after treatment shows the absence of NF200 afferent fibers innervating inner hair cells (IHC, arrowheads). Also shown is a control ear (insert in B). The absence of radial afferent fibers allows a clear view of inner spiral bundle including both efferent and afferent fibers projecting into the outer hair cell $(\mathrm{OHC})$ region. Numerous external spiral fibers are seen tracking spirally into the $\mathrm{OHC}$ region, including long, thin type II afferent fibers (arrows). C, E, G NF $200^{+}$afferent fibers innervating IHCs (arrowheads) in the middle turn of another control mouse. Surface preparation stained with NF 200 (green) and choline acetyltransferase (ChAT, red). The dashed lines indicate the location of the habenula perforata where nerve processes of type I SGNs lose their myelin sheath prior to entering the organ of Corti. White arrows indicate the long, thin type II afferent fibers. D, F, H Loss of NF $200^{+} / \mathrm{ChAT}^{-}$ afferent fibers innervating IHCs in the middle turn of another mouse at 30 days post-treatment. Radial NF200 ${ }^{+}$fibers under IHCs disappear (arrowheads), whereas small thin NF $200^{+} / \mathrm{ChAT}^{-}$afferent fibers are still occasionally seen in the $\mathrm{OHC}$ region (white arrow). The inserts are the enlarged images of areas marked by a white arrow. The staining patterns of $\mathrm{ChAT}^{+}$efferent fiber in the treated ear innervating $\mathrm{OHCs}$ are similar to those seen in a control ear. Numerous $\mathrm{ChAT}^{+}$ clusters are seen beneath IHC areas (asterisk). Scale bar, $15 \mu \mathrm{m}$ in $\mathbf{A}$ and $\mathbf{B}$; $20 \mu \mathrm{m}$ in $\mathbf{H}$ (applies to $\mathbf{C}-\mathbf{H}$ ).
Hyperplasia of Glia-Like Cells in Injured Auditory Nerve

Following loss of type I SGNs, an activation of glia-like cells was seen in the injured spiral ganglia, most notably in the 3- and 7-day post-treatment groups (Fig. 6). Figure 6D was reconstructed from about 20 digital images $(\times 63$ magnification) that captured portions of Rosenthal's canal, the osseous spiral lamina, and the apical, middle, and upper basal 

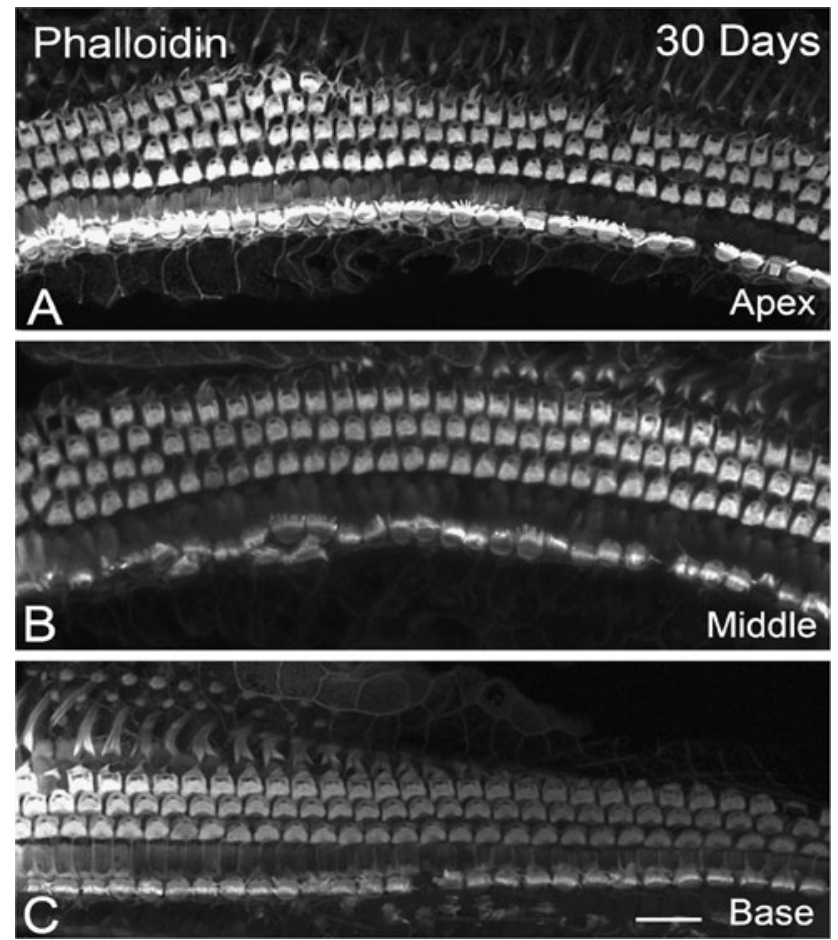

FIG. 5. Cochlear sensory hair cells after ouabain treatment. A-C Surface preparations from the apical, middle, and basal turns stained with phalloidin in a mouse at 30 days post-treatment. Almost all IHCs and OHCs were intact. Scale bar, $20 \mu \mathrm{m}$ in C (applies to A-C).

portions of the organ of Corti. This high-resolution imaging procedure allowed us to characterize precisely the pathological changes in the ouabain-treated auditory nerves. Hyperplasia of glia-like cells appeared in Rosenthal's canal and the osseous spiral lamina in the treated ears (Fig. 6B-D). In addition, enlarged microvasculature was frequently seen within Rosenthal's canal and the osseous spiral lamina of the treated ears (Fig. 6D).

Ultrastructural examination of the ouabain-treated ears revealed a spatial and temporal heterogeneity of glia-like cells in the injured auditory nerve (Fig. 7). Within the Rosenthal's canal, the diameters of these cells ranged from 6 to $8 \mu \mathrm{m}$ (Fig. 7A-C). The nuclei of the glia-like cells at 3 and 7 days post-treatment were enriched with light electron-dense euchromatin, suggesting active transcription in these cells. In the osseous spiral lamina, these glia-like cells were mostly elongated and spindle-shaped (Fig. 7D). By 30 days post-treatment, the nuclei of the glia-like cells within Rosenthal's canal mostly appeared to have prominent heterochromatin and less euchromatin (Fig.7G). The presence of microvasculature was noted in Rosenthal's canal along with surrounding fibroblastlike cells with irregular-shaped nuclei (Fig. 7D). In addition, macrophages and/or microglia were infrequently seen in the ouabain-treated ears (Fig. 7E).
Total cell counts in control and treated ears were performed on frozen sections using bisbenzimide (Hoescht 33342) nuclear staining. Figure $7 \mathrm{H}$ shows that the total cell density in 1, 3, and 7 days posttreatment nerves are equal to that of controls, suggesting an influx of new cells to replace the lost SGNs. However, the number of glia-like cells was reduced by 14 days post-treatment (Fig. 7G). By 30 days post-treatment, the density of total cells within Rosenthal's canal was about one half of the density at 1, 3, and 7 days post-treatment. The observed reduction in glial cell numbers after 14 days suggests that glial degeneration was occurring.

\section{Sox $2^{+}$Expression in Normal and Injured Auditory Nerve}

Sox2 expression in normal and ouabain-treated auditory nerves was examined and quantified by RTPCR and Western blot assays (Fig. 8). As shown in Fig. 8A, the levels of Sox2 mRNA expression at 1, 3, and 7 days post-treatment were significantly greater than that of controls (ANOVA, $p<0.01$ ). The Sox2 mRNA levels at 3 days after treatment were sevenfold greater than that of controls. We also noted a trend toward increased Sox2 mRNA expression at 14 days post-treatment compared to controls, but this difference was not statistically significant (ANOVA, $p>0.05$ ). Hes5 acts as both upstream and downstream target of Sox2 (Bani-Yaghoub et al. 2006; Hartman et al. 2009; Takanaga et al. 2009) and was significantly increased 3 days post-treatment (ANOVA, $p<0.05$; Fig. 8B), reconfirming the result of up-regulation of Sox2 expression in ouabain-treated auditory nerves. A trend toward increased Hes5 mRNA levels at 7 days post-treatment was also observed (ANOVA, $p>0.05$ ). Similarly, Western blots revealed that Sox2 expression (34 kDa) increased about two to threefold at 3 and 7 days post-treatment compared to that of controls (Fig. 8C). In contrast, the expression of NF 200 and $\beta$ tubulin was reduced after ouabain treatment, correlating with the significant loss of spiral ganglion neurons.

Additional studies examined the cellular localization of Sox2 expression using immunofluorescent staining. Figure $9 \mathrm{~A}-\mathrm{C}$ shows the nuclear staining pattern of Sox2 in a normal auditory nerve. The morphological characteristics of these Sox $2^{+}$cells suggest that they are non-neuronal cells within the auditory nerve (Fig. 9A-F). Dual-staining Sox2 with the neural marker NF 200 revealed that the intensive Sox2 expression was present in the nuclei of the small non-neuronal (NF 200-) cells in both control and ouabain-treated ears (Fig. 9D-F).

Following ouabain treatment, the number of Sox $2^{+}$ cells within Rosenthal's canal significantly increased at 

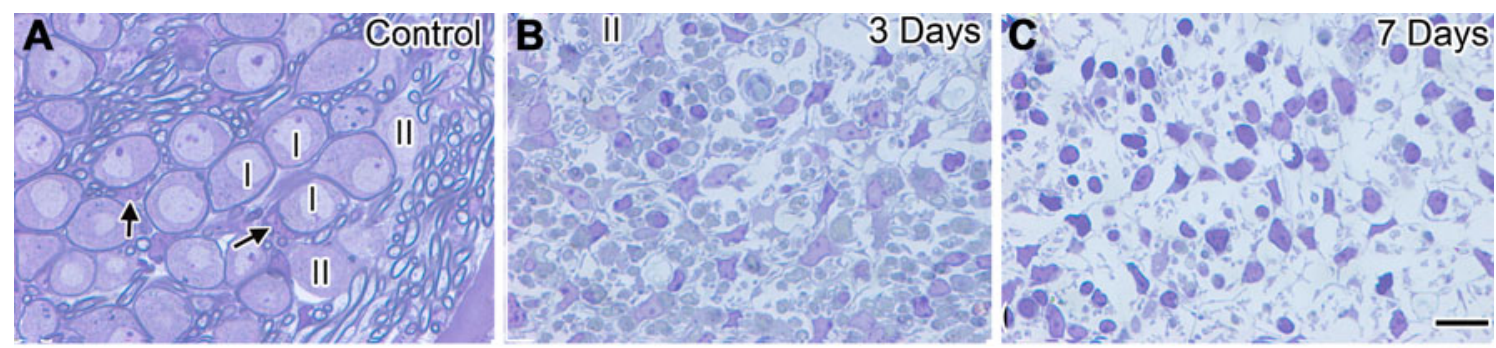

D

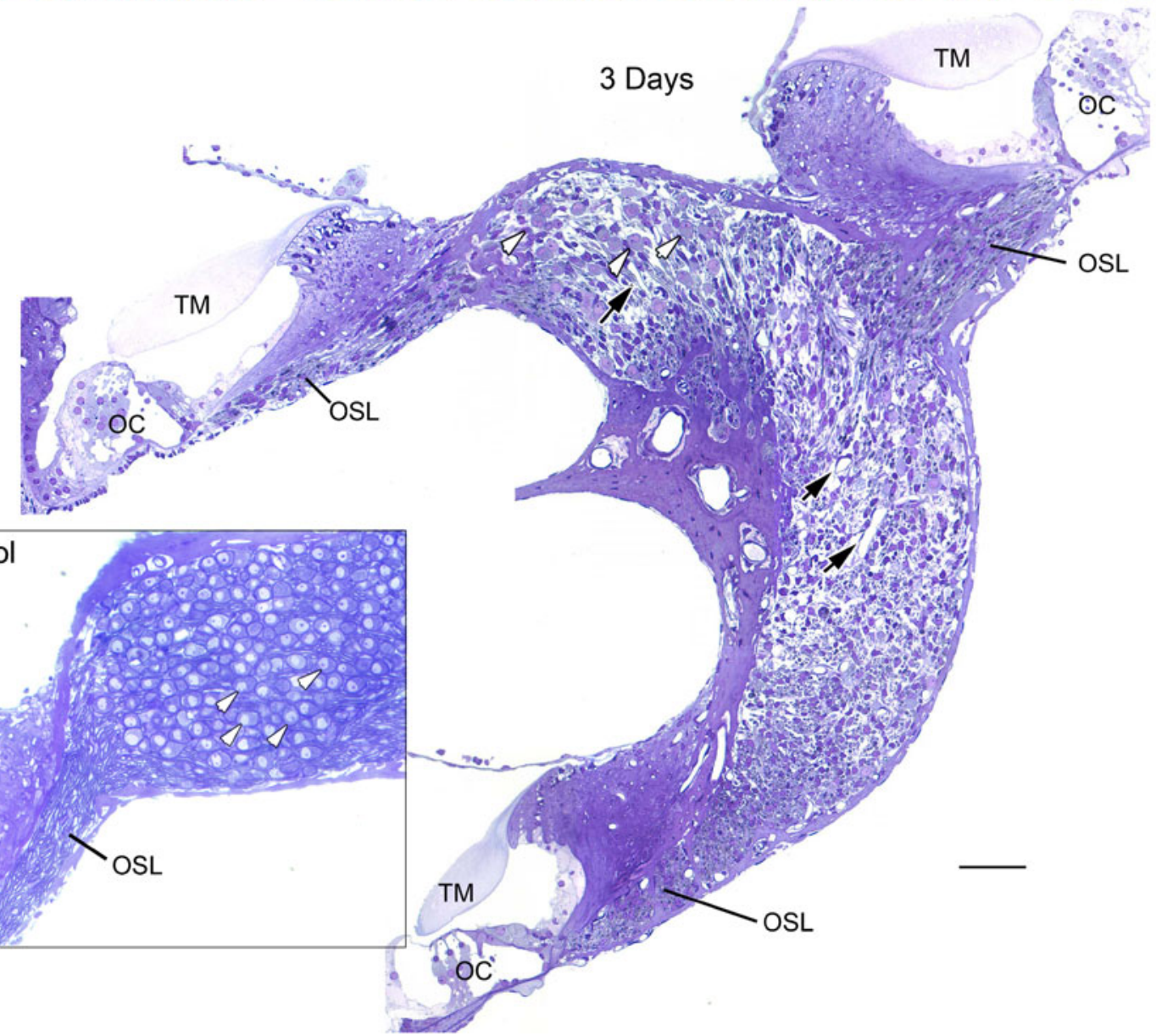

FIG 6. Hyperplasia and hypertrophy of glia-like cells in injured auditory nerve. Semi-thin radial sections were stained with toluidine blue. A Section taken from a control ear shows profiles of type I ( $I$ ) and type II (II) SGNs as well as Schwann cells (arrowheads). B three days after ouabain treatment, most spiral ganglion cells were apoptotic or lost. C Sevendays after treatment, most of the spiral ganglion cell bodies were absent and numerous spindle-shaped cells, interpreted as glia-like cells, were present within the Rosenthal's canal. D Hyperplasia and hypertrophy of glia-like cells within the osseous spiral lamina (osl) and Rosenthal's canal in the apical, middle, and upper basal turns of another mouse at 3 days post-treatment. White arrowheads indicate a few surviving SGNs and black arrows indicate several areas of microvasculature. E Normal profiles of glial cells and SGNs (white arrowheads) within the osl and Rosenthal's canal in a lower apical turn taken from a control ear. TM tectorial membrane, OC organ of Corti. Scale bars, $7 \mu \mathrm{m}$ in $\mathbf{C}$ (applies to $\mathbf{A}-\mathbf{C}$ ); $45 \mu \mathrm{m}$ in $\mathbf{D}$.
3 days post-treatment and reached its maximum level at 7 days post-treatment (Fig. 9F, G; ANOVA, $p<0.05$ ). The density (cells $/ \mathrm{mm}^{2}$ ) of Sox $2^{+}$cells in the apical, middle, and basal turns was 3,203, 3,385, and 3,027 for controls and 7,438, 8,427, and 5,542 for the 7 days post-treatment ears, respectively. The number of Sox $2^{+}$cells was reduced by 14 days post-treatment and similar to the control level by 30 days post- treatment. In the osseous spiral lamina, little or no staining of Sox $2^{+}$cells was present in control ears (Fig. 10A-C). However, Sox2 ${ }^{+}$cells appeared in ouabain-treated ears, beginning at 1 day and reaching its maximum level at 7 days after ouabain treatment (Fig. 10D-G). Again, little or no staining of Sox $2^{+}$ cells was present by 30 days post-treatment (Fig. 10G). PI nuclear staining revealed that Sox2 $2^{+}$cells in the 


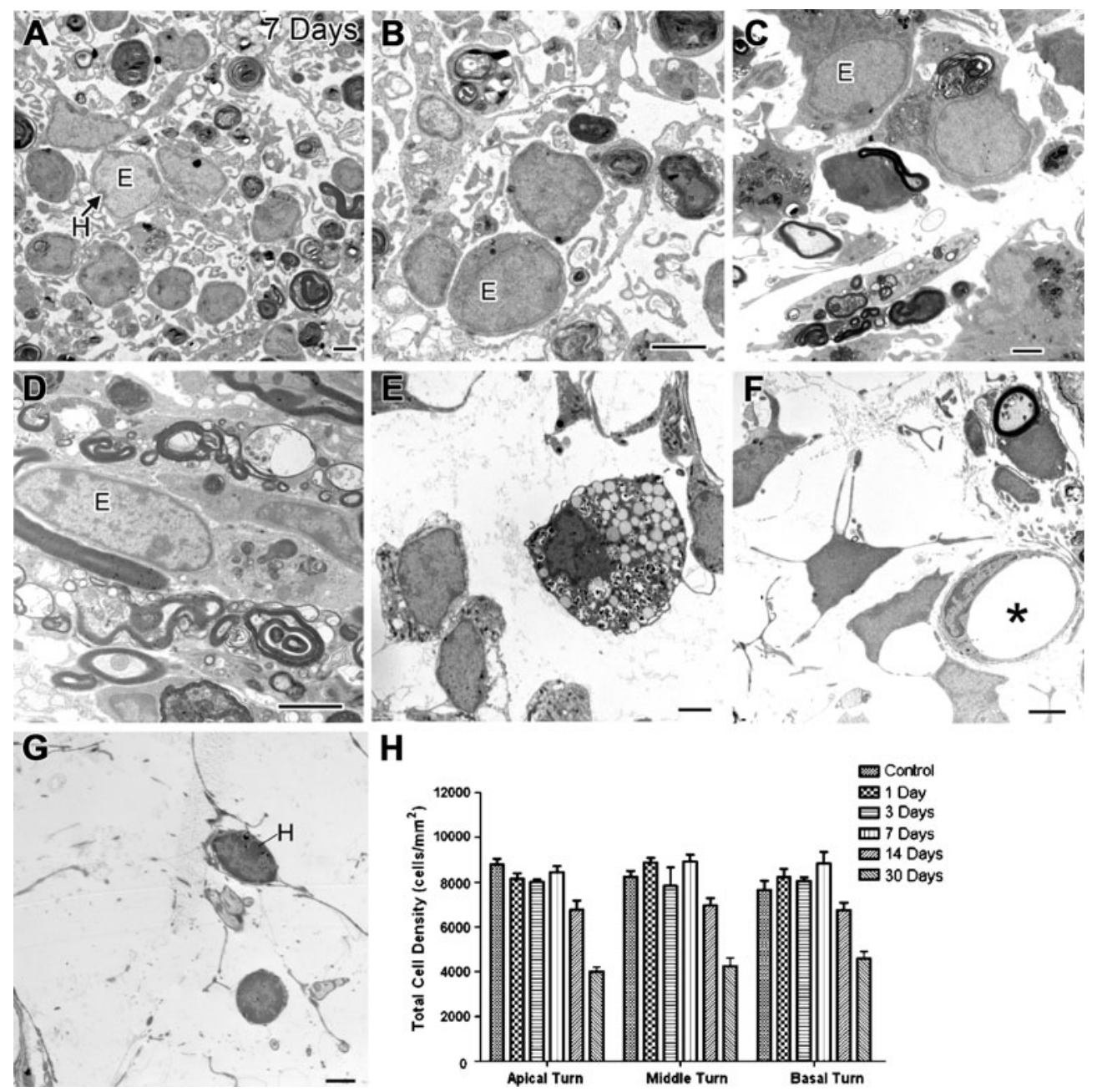

FIG. 7. Ultrastructure of glia-like cells in injured auditory nerve. A-F Mice 7 days post-treatment. G A mouse 30 days post-treatment. A-C Glia-like cells in Rosenthal's canal of ouabain-treated mice show profiles of nuclei with prominent euchromatin and less dense hererochromatin. $E$ euchromatin, $H$ heterochromatin. D A normal-looking glia-like cell within the osseous spiral lamina. E A microglia-like cell within Rosenthal's canal with numerous vesicles and cellular debris suggesting an active phagocytosis. F Glia-like cells with microvasculature within Rosenthal's canal (asterisk). Arrowhead indicates a survived SGN process. G At 30 days following ouabain exposure, most glia-like cells disappear, leaving only a few surviving cells with enriched, dense heterochromatin in the nuclei. $\mathbf{H}$ Mean density of the total cells within Rosenthal's canal in the apical, middle, and basal turns of control, 1-, 3-, 7-, 14-, and 30-day post-treated ears. Scale bars, $2 \mu \mathrm{m}$ in A-G. osseous spiral lamina have elongated and spindleshaped nuclei similar to those of the glia-like cells seen in the ultrastructural examination of injured auditory nerves (Figs. 7D and 10D-F).

To further confirm the glial phenotype of Sox $2^{+}$ cells, dual immunostaining with two separate glial markers was employed for control (data not shown) and 7 days post-treatment mice (Fig. 11). Figure 11AC shows that most of Sox $2^{+}$cells stain positively for S100, a commonly used Schwann cell marker for mouse and rat auditory nerve (Hansen et al. 2001; Hurley et al. 2007; Whitlon et al. 2009). Dual immunostaining of Sox2 and Sox10 showed that the majority of Sox $2^{+}$cells were co-labeled with Sox10 in ouabain-treated nerves (Fig. 11D-F). The Sox10 anti- body revealed a nuclear staining pattern in glial cell nuclei similar to the previous observations in mouse inner ear (Whitlon et al. 2009; Puligilla et al. 2010).

\section{Increased BrdU ${ }^{+}$Cells in Injured Auditory Nerve}

The use of BrdU incorporation assays revealed that very few cells were mitotic in normal auditory nerves (Fig. 12A, E). These results agree with previous observations on the proliferative activity of normal adult inner ear (Ruben 1967; Roberson and Rubel 1994; Yamashita et al. 1999; Lang et al. 2003). According to morphological characteristics, the $\mathrm{BrdU}^{+}$cells in the control ears are most likely the 

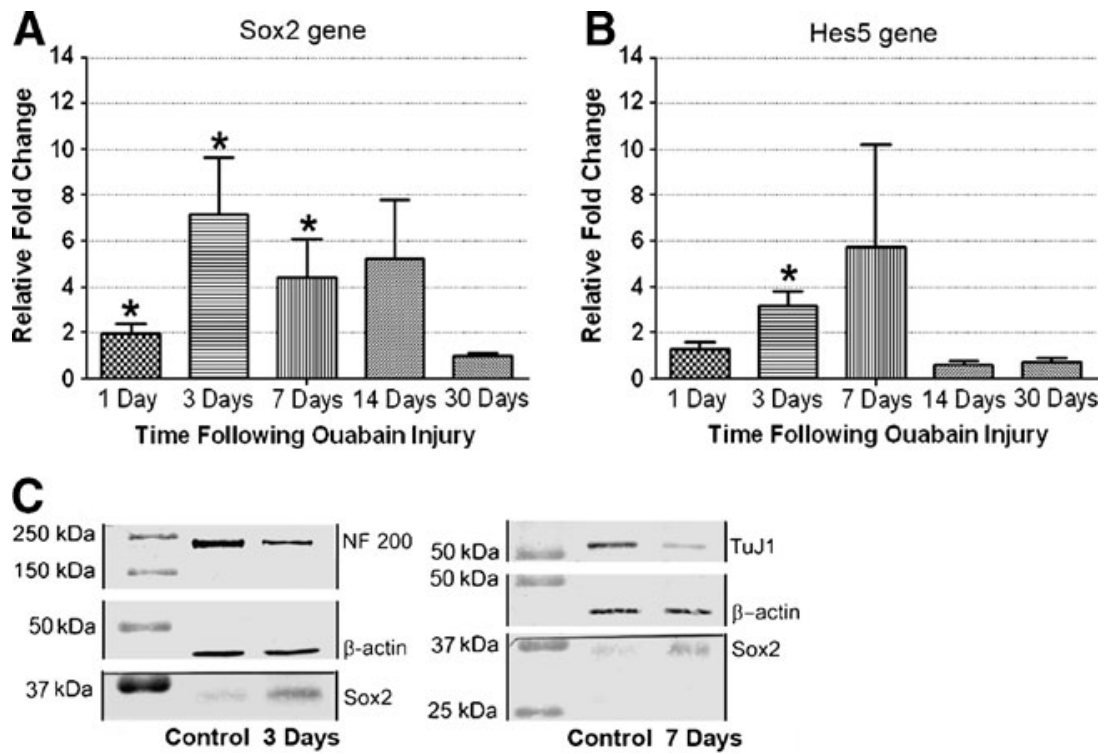

non-neuronal cells such as glial cells, fibroblasts, and vascular endothelial cells. Following ouabain exposure, the number of $\mathrm{BrdU}^{+}$cells was significantly increased 3 days after treatment and reached a peak level at 7 days post-treatment (ANOVA, $p<0.05$; Fig. 12B, C). At 14 and 30 days post-treatment, the number of $\mathrm{BrdU}^{+}$cells was reduced (Fig. 12E).

\section{$\mathrm{BrdU}^{+} / \mathrm{Sox}^{+}$Cells in Injured Auditory Nerve}

To determine the extent of proliferation in Sox $2^{+}$cells, dual staining for BrdU with Sox2 was performed and quantitatively analyzed in the control and ouabaintreated ears (Fig. 12A-C, F, G). Following ouabain exposure, the number of $\mathrm{BrdU}^{+}$cells was significantly increased at 7 days post-treatment (ANOVA, $p<0.05$; Fig. $12 \mathrm{~B}-\mathrm{E}$ ). We observed a bimodal $\mathrm{BrdU}^{+} / \mathrm{Sox}^{+}$cell distribution (Fig. 12F), though relatively low densities of $\mathrm{BrdU}^{+} / \mathrm{Sox}^{+}$cells at 14 days post-treatment suggested a loss of Sox $2^{+}$proliferating cells by this time. Between $64 \%$ and $83 \%$ of $\mathrm{BrdU}^{+}$cells were co-labeled with Sox2 in the apical, middle, and basal turns of those ouabaintreated auditory nerves (Fig. 12G). Similar results of dual staining for BrdU with Sox2 were also seen within the osseous spiral lamina (data not shown). Taken together, our data demonstrate that a proliferating Sox $2^{+}$glial cell population is a main contributor to the $\mathrm{BrdU}^{+}$cells in the injured auditory nerves. To determine the overall proliferative ability of Sox $2^{+}$ glial cells in injured auditory nerves, percentages of $\mathrm{BrdU}^{+}$cells in $\mathrm{Sox}^{+}$cell populations were also analyzed as shown in Fig. 12H. About $6-10 \%$ of Sox $2^{+}$cells stained positive with BrdU at 7 days posttreatment, suggesting that a subpopulation of Sox $2^{+}$
FIG. 8. Up-regulation of Sox2 expression in injured auditory nerve. A, B Realtime RT-PCR assays show fold changes for Sox 2 and Hess 5 mRNA expression in the auditory nerves taken from control, 1-, 3-, 7-, 14-, and 30-day post-treated ears. Data are present as fold changes from control value \pm standard error $(n=3-5$ per group). C Western blot assays with Sox 2 antibody show a single $34-\mathrm{kDa}$ band of endogenous Sox2 in normal, 3-, and 7day post-treated ears. Expression levels of Sox2 increase after ouabain exposure, whereas the expression levels of NF 200 and $\beta$-tubulin decrease due to losses of SGNs in ouabain-treated ears. $\beta$-actin blotting was used to verify equal protein loading. glial cells in the auditory nerve of adult mouse inner ear contains self-renewing properties.

\section{DISCUSSION}

Type I SGN Degeneration and Glial Cell Reactivation in Injured Auditory Nerve

Ouabain is a cardiac glycoside that specifically binds to the Na,K-ATPase and inhibits its activity. Previous studies have shown that ouabain induces apoptosis of cortical neurons and is accompanied by increased intracellular $\mathrm{Ca}^{2+}$ and $\mathrm{Na}^{+}$and released cytochrome c (Xiao et al. 2002). Here, we have established a mouse model of type I SGN degeneration through the application of ouabain to the round window of the adult $\mathrm{CBA} / \mathrm{CaJ}$ mouse. Similar to our previous studies in the adult gerbil (Schmiedt et al. 2002; Lang et al. 2005), ouabain can selectively and permanently induce the degeneration of type I SGNs while leaving type II SGNs, efferent fibers, and sensory hair cells relatively intact in the adult mouse inner ear. Significant loss of auditory function and degeneration of type I SGNs were seen as early as 1 day after ouabain exposure. Although some surviving type I SGNs were present in the apical turns 1 day after ouabain exposure, these neurons were eventually lost 3 days or later after treatment. Thus, similar to the gerbil model, the degeneration of type I SGNs in response to ouabain treatment is quite rapid and follows an apoptotic-like degeneration (Schmiedt et al. 2002). The selective survival advantage of type II over type I neurons has also been seen in other degeneration models, e.g., in ototoxic lesions (Spoendlin 1975; Lim 1976; Leake and Hradek 1988), noise trauma (Spoendlin 1975; Lim 1976), or 

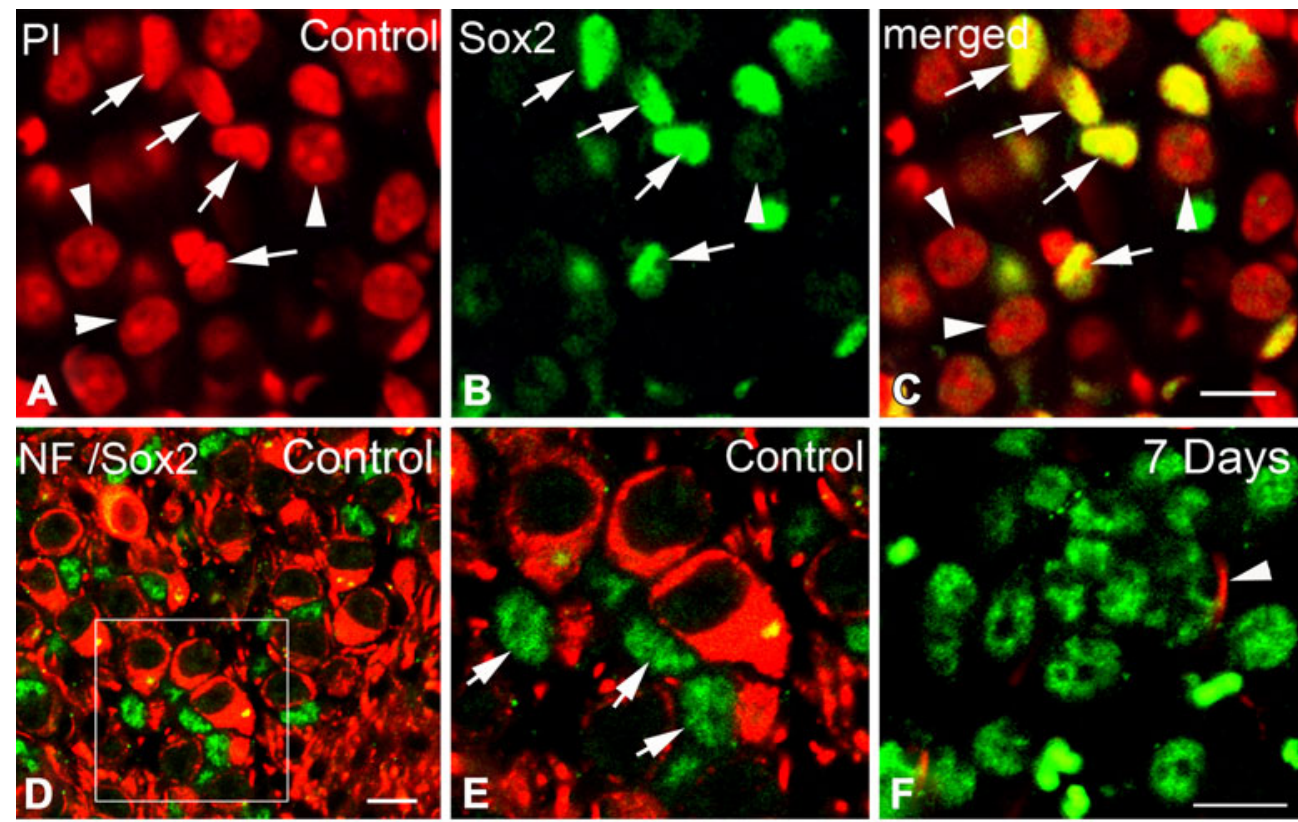

\section{G}

\section{Sox2 positive cells in Rosenthal's canal}

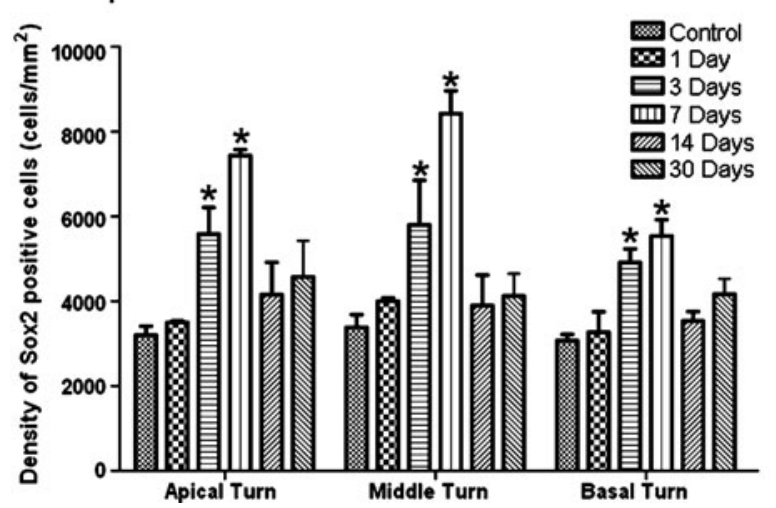

FIG. 9. Increased Sox $2^{+}$cells within Rosenthal's canal in injured auditory nerves. A-C Nuclear staining pattern of Sox2 antibody (green) in normal auditory nerve. PI nuclear counterstaining (red) reveals nuclear profiles of Sox $2^{+}$cells. The nuclei of SGNs are identified by their large spherical nuclei (arrowheads). Note that SGNs do not express or express a very low level of Sox 2 and were not considered as Sox $2^{+}$cells in this study. D, E Dual immunostaining for Sox2 (green) and a neuronal marker, NF $200(N F$, red) reconfirms that high-intensity expression of Sox2

appears in the nuclei of Schwann- and or satellite-like cells (arrows). E Enlarged image of corresponding boxed area in D. F Sox ${ }^{+}$cells in the auditory nerve 7 days after ouabain treatment. An arrowhead indicates a surviving SGN process. G Mean density of Sox ${ }^{+}$ cells within the Rosenthal's canal in the apical, middle, and basal turns from control, 1-, 3-, 7-, 14-, and 30-day post-treated ears ( $n=3-6$ per group). Scale bars, $8 \mu \mathrm{m}$ in $\mathbf{C}$ (applies to $\mathbf{A}-\mathbf{C}$ ); $7 \mu \mathrm{m}$ in $\mathbf{D} ; 7 \mu \mathrm{m}$ in $\mathbf{F}$ (applies to $\mathbf{E}-\mathbf{F}$ ).

transection of the cochlear nerve (Spoendlin 1975). A recent study revealed that differentiated expression patterns of $\mathrm{Na}, \mathrm{K}$-ATPase $\alpha$ isoforms are present in types I and II SGNs with Na,K-ATPase, $\alpha 3$ being present in type I SGNs but not in type II neurons (McLean et al. 2009). Further studies on the molecular and functional characterization of these two types of neurons are needed to understand their differential response to insults.

This study demonstrates that glial cells in the adult auditory nerve undergo hypertrophy and hyperplasia following type I SGN degeneration. A similar histopathological change has been termed "reactive astrogliosis" or "glial scar" in the central nervous system and is characterized as a proliferation of astrocytes in damaged brain (Sofroniew 2009). In the retina, Müller cell gliosis occurs in response to retinal diseases and injuries (Bringmann et al. 2006). Application of ouabain to the adult mouse inner ear provides an excellent model for understanding the roles of cochlear glial responses in SGN degeneration and sensorineural hearing loss.

\section{Expression of Sox2 in Normal Adult Auditory Nerve}

Sox2 expression is detected in the prosensory regions prior to sensory cell differentiation, in sensory hair 

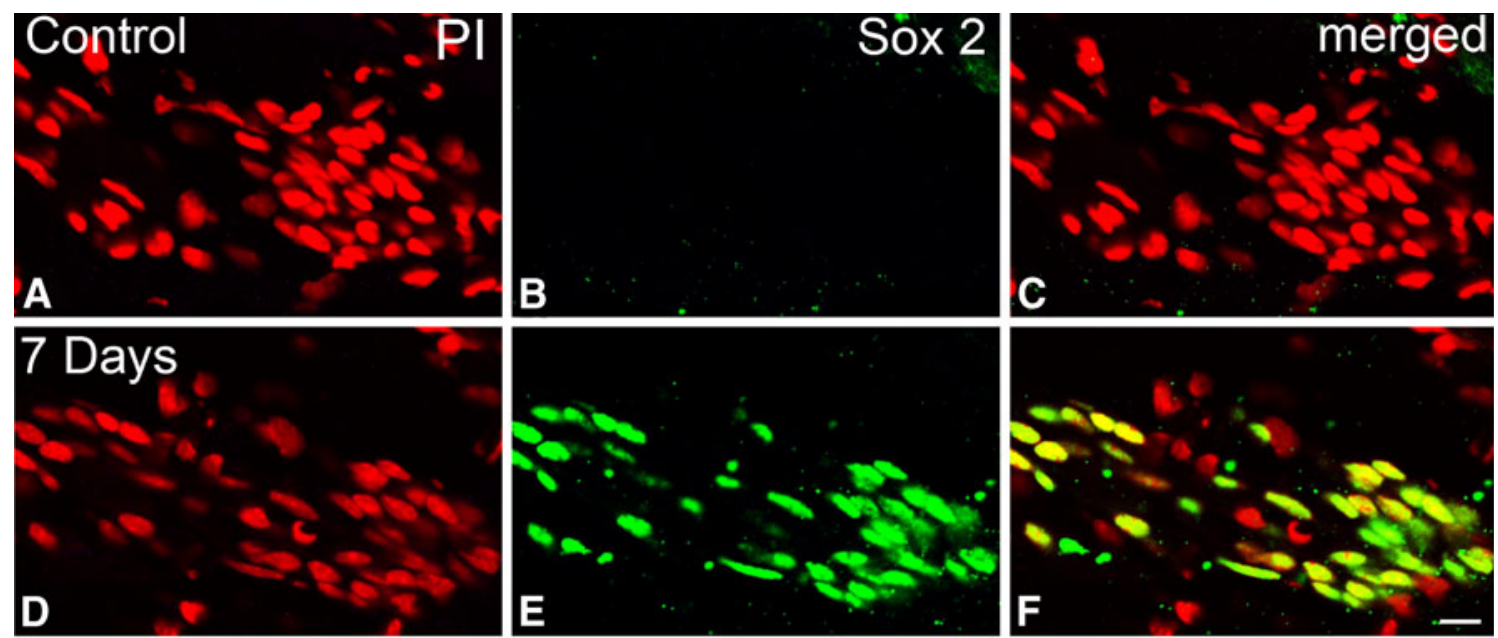

\section{G}

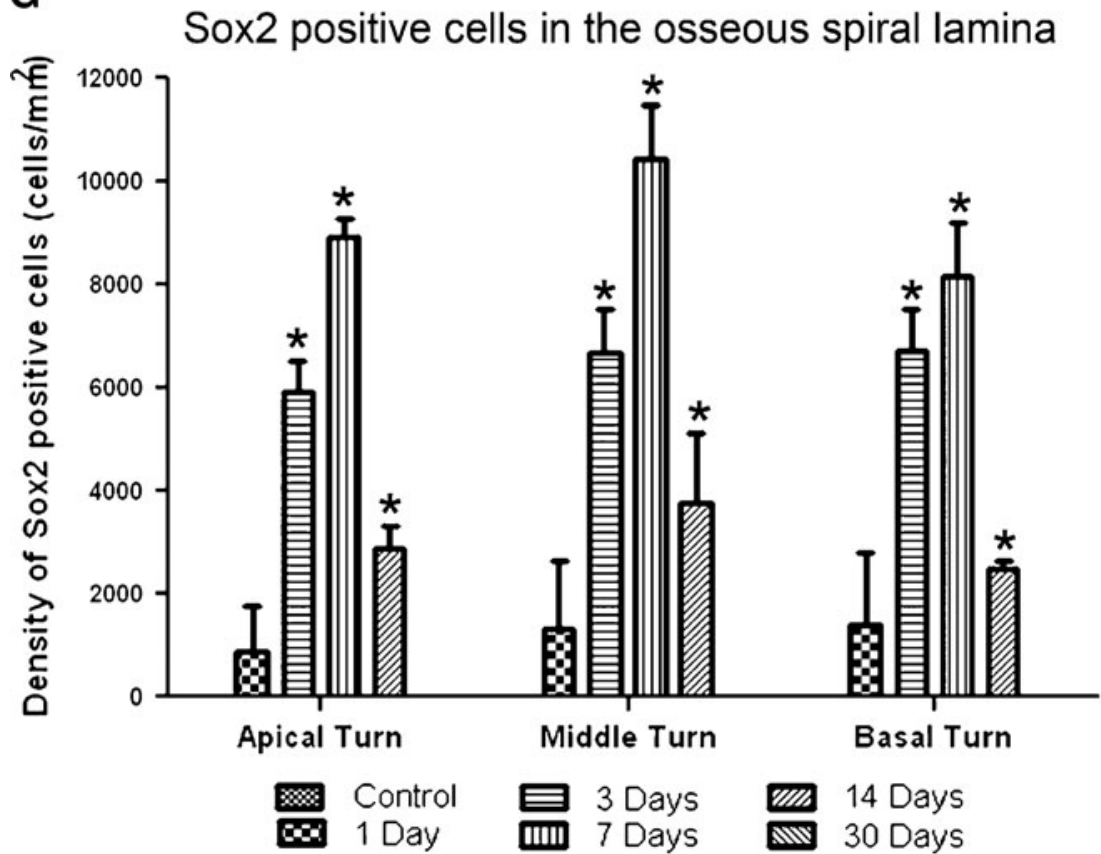

FIG. 10. Increased Sox $2^{+}$cells in the osseous spiral lamina in injured auditory nerves. A-C Glial cells within osseous spiral lamina of control ears are not stained with Sox2 antibody. Nuclei were counterstained with PI (red). D-F Many cells stained positively with Sox2 antibody

cells, and in supporting cells of both the auditory and vestibular organs at later embryonic stages (Hume et al. 2007; Neves et al. 2007; Mak et al. 2009). Gene lossor gain-of-function studies have demonstrated that Sox2 is necessary for the formation of sensory epithelia as well as the differentiation and maintenance of sensory and neuronal cells in the developing inner ear (Kiernan et al. 2005; Dabdoub et al. 2008; Puligilla et al. 2010). In the adult mouse ear, Sox2 is expressed in supporting cells and a subpopulation of vestibular hair cells (Oesterle et al. 2008). Neves et al. (2007) reported that Sox2 is expressed in the cochleovestibular ganglion of the developmental (green) in a mouse 7 days after ouabain treatment. G Mean density of Sox $2^{+}$cells within the osseous spiral lamina in the apical, middle, and basal turns from control, 1-, 3-, 7-, 14-, and 30-day post-treated ears ( $n=$ 3-6 per group). Scale bar, $5 \mu \mathrm{m}$ in $\mathbf{F}$ (applies to $\mathbf{A}-\mathbf{F}$ ).

chicken ear. Here, we report that Sox2 is expressed in a subset of glial cells in the auditory nerve of the adult mouse inner ear. More specifically, the glial cells in Rosenthal's canal, but not those in the osseous spiral lamina, express Sox2. To our knowledge, this is the first time that the functional heterogeneity of cochlear cells has been differentiated by specific expression patterns using a glial-related cell marker.

\section{Sox2 Up-regulation in Injured Adult Auditory Nerve}

We did observe an up-regulation of Sox2 expression in auditory nerve following type I SGN degener- 

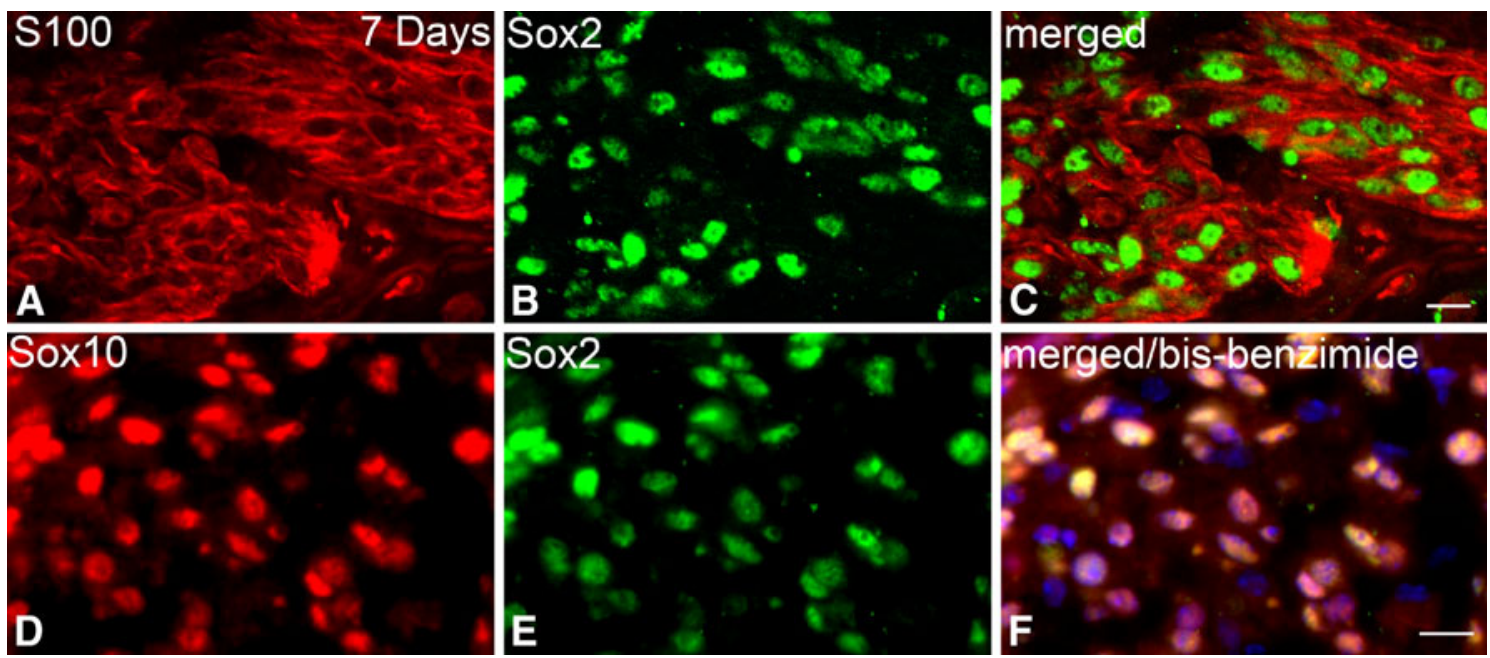

FIG. 11. Sox $2^{+}$cells stain positively for neural glial marker in injured auditory nerve. A-C Dual immunostaining for S100 (red) and Sox2 (green) in the auditory nerve of a mouse 7 days after ouabain treatment. D-F Dual immunostaining for Sox10 (red) and Sox2 (green) in the mouse shown in $\mathbf{A}-\mathbf{C}$. Nuclei were counterstained with bis-benzimide (blue). Scale bar, $10 \mu \mathrm{m}$ in $\mathbf{F}$ (applies to $\mathbf{A}-\mathbf{F}$ ). ation. Increased Sox $2^{+}$glial cells were seen in both Rosenthal's canal and the osseous spiral lamina 3 and 7 days post-treatment. Certain glial cells in the osseous spiral lamina do not express Sox2 and remain quiescent in the normal inner ear; however, ouabain-induced injury results in the up-regulation of Sox2 gene transcription and subsequent proliferation. Similarly, previous studies have shown that a group of Schwann cells in the mouse sciatic nerve and a subset of astrocytes in mouse neocortex, which do not normally express Sox2, do in fact reexpress Sox2 and resume proliferation in response to mechanical injury (Le et al. 2005; Bani-Yaghoub et al. 2006). In an elegant study using conditional glutamate aspartate transporter (GLAST) transgenic mouse, and astrocyte-targeted lentiviral vectors, Buffo et al. (2008) reported that quiescent astrocytes in adult mouse cerebral cortex can change their phenotype and obtain neural progenitor cell-like properties, including the capacity for self-renewal after stab wound injury. Investigations of regeneration in the retina have revealed some evidence that Müller glia can dedifferentiate and proliferate after retinal damage (Fischer and Reh 2001; Karl et al. 2008). These findings strongly suggest that mature neural glial cells in both the central and peripheral nervous systems can change their phenotype (and even reenter into a dedifferentiated status in some cases) if within an appropriate "injury microenvironment."

Specific lesion paradigms may serve as triggers for the phenotypic changes of mature glial cells. Injury itself within the central and peripheral nervous systems can induce the up-regulation of endogenous growth factors such as FGF2, GFAP, ciliary neurotrophic factor (CNTF), vascular endothelial growth factor, and platelet-derived growth factor (Silver and Miller 2004; Aldskogius and Kozlova 1998; Stowe et al. 2007). The exposure of astrocytes to either FGF2 and CNTF significantly increased the number of Sox $2^{+}$ proliferating astrocytes, suggesting that either an FGF2- or CNTF- mediated pathway may be involved in the regulation of Sox2 expression after acute injury (Bani-Yaghoub et al. 2006). Our previous studies have also shown that application of ouabain to gerbil and mouse ears resulted in the elevated expression of FGF2, GFAP, and matrix metalloproteinase 9 in the auditory nerve (Lang et al. 2006a; Jyothi et al. 2010). Further work is required to determine which of the regulatory elements in Sox2 gene up-regulation is mediated by these growth factor-related pathways.

\section{Sox ${ }^{+}$Glial Cell Proliferation in Injured Auditory Nerve}

Our data show that up-regulation of Sox2 expression is associated with the increased cell proliferation observed in the ouabain-injured auditory nerves. A majority of $\mathrm{BrdU}^{+}$cells (about $70 \%$ ) in the injured auditory nerve also expressed Sox2. Numerous studies have suggested that Sox2 is important for the maintenance of tissue homeostasis, regulation of selfrenewal, and differentiation of neural cells (Graham et al. 2003a, b; Ferri et al. 2004; Le et al. 2005). Using adenovirus-mediated gene modification, Le et al. (2005) have shown that enforced Sox2 expression in cultured Schwann cells led to increased proliferation and also maintained the Schwann cells in an undifferentiated state. In an in vivo model of sciatic nerve injury, increased Sox2 staining appeared in the immature Schwann cells of the injured nerve 4 days 

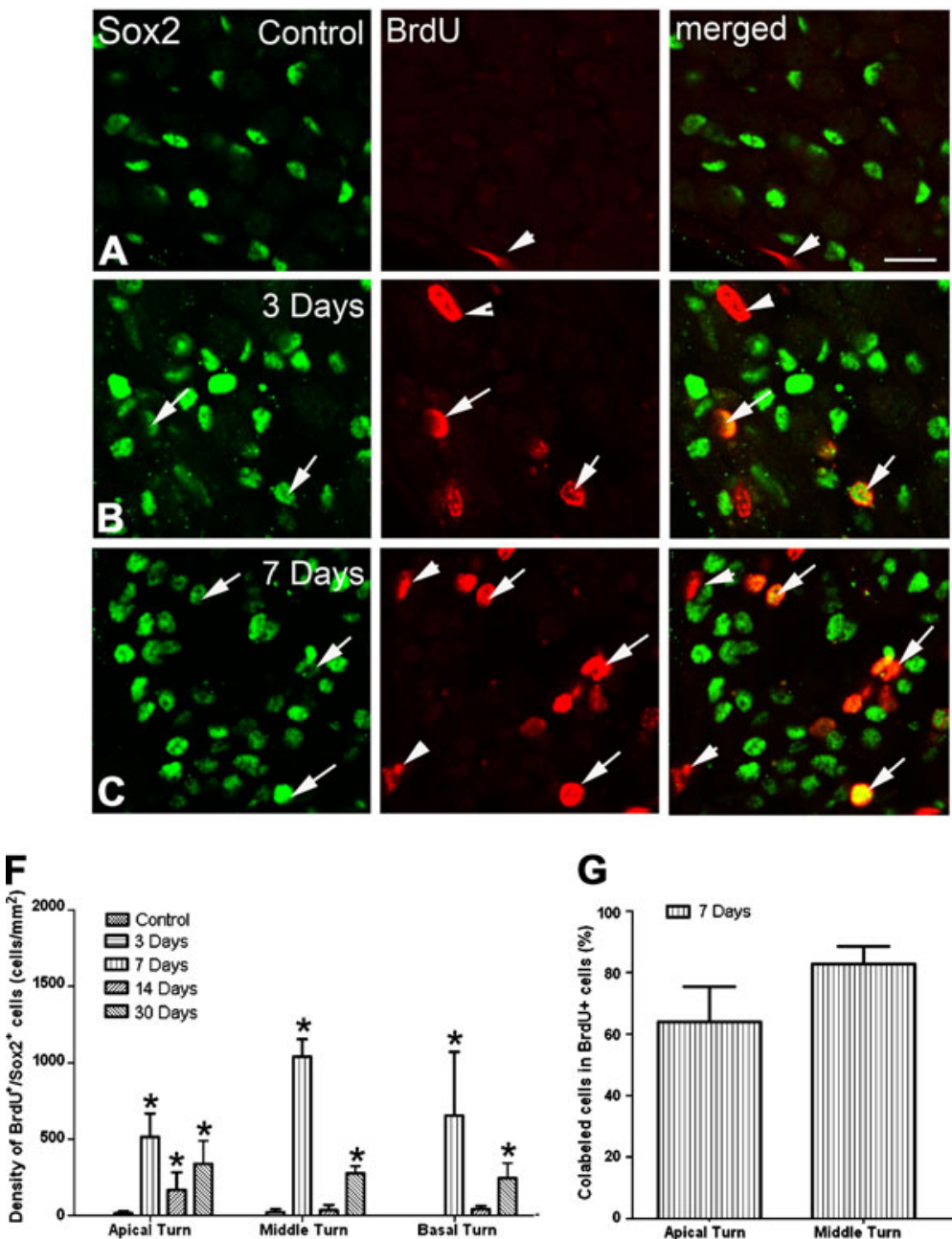

G

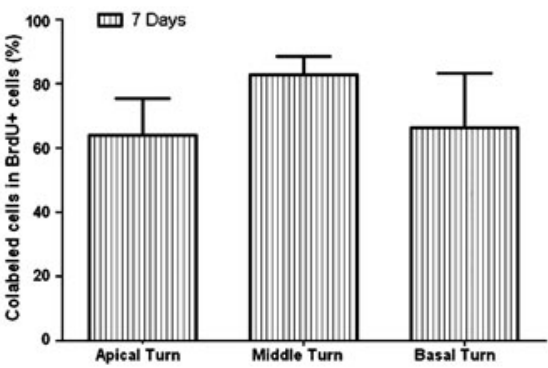

H
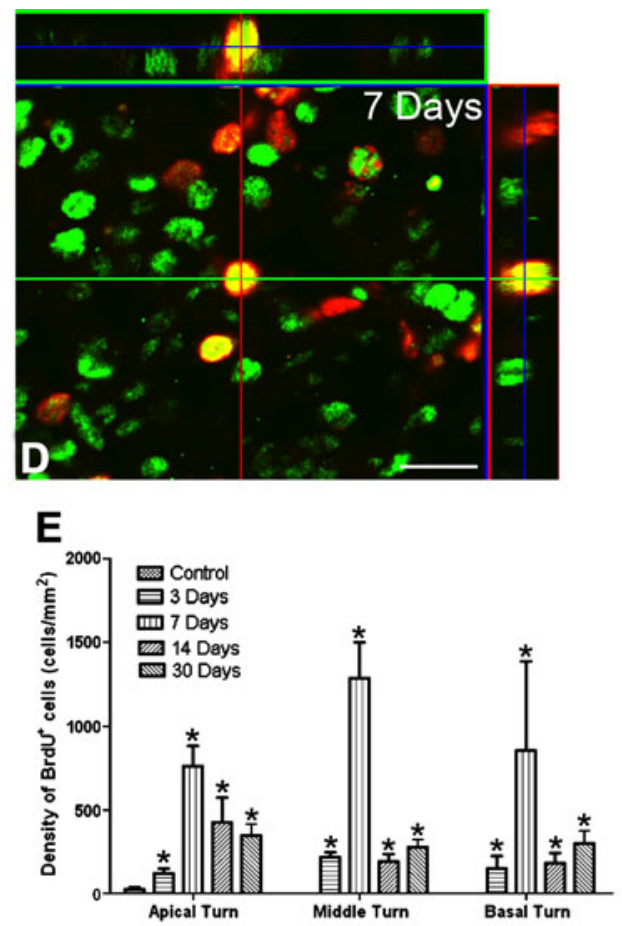

FIG. 12. Increased $\mathrm{BrdU}^{+}$and $\mathrm{BrdU}^{+} / \mathrm{Sox}^{+}$cells in injured auditory nerve. A Dual immunostaining for Sox2 (green) and BrdU (red, arrows) in a normal auditory nerve showing only one BrdU ${ }^{+}$cell that was not co-labeled with Sox2 (arrowheads). B, C Increased number of $\mathrm{BrdU}^{+}$cells in mice 3 and 7 days after ouabain treatment. A majority of $\mathrm{BrdU}^{+}$cells were co-labeled with Sox2 (yellow, arrows). D Three-dimensional reconstructed confocal image shows a cell co-labeled for Sox 2 and BrdU in a mouse 7 days after ouabain treatment. E Mean density of BrdU ${ }^{+}$cells within the Rosenthal's canal in the apical, middle, and basal turns of control, 1-, 3-, 7-, 14-, and 30-day post-treated ears ( $n=3-6$ per group). $\mathbf{F}$ Mean density of $\mathrm{BrdU}^{+} / \mathrm{Sox}^{+}$cells within Rosenthal's canal. G Mean density of $\mathrm{BrdU}^{+} / \mathrm{Sox}^{+}$cells among the total BrdU ${ }^{+}$cells. $\mathbf{H}$ Mean density of $\mathrm{BrdU}^{+} / \mathrm{Sox}^{+}$cells among the total Sox $2^{+}$cells. Scale bars, $15 \mu \mathrm{m}$ in C (applies to A-C); $15 \mu \mathrm{m}$ in $\mathbf{D}$. after a nerve crush. In the current study, the findings of up-regulation of Sox2 expression along with proliferation of a subset of Sox $2^{+}$glial cells in the auditory nerve after ouabain treatment suggest that Sox2 also plays an important role in regulating the injuryrelated activation of glial cells in the adult mouse inner ear.

In the central nervous system, a recent study has shown that a subset of Sox $2^{+}$glia-like cells are able to produce neurons, astrocytes, and Sox $2^{+}$undifferentiated cells in the subgranular zone of the adult hippocampus (Suh et al. 2007). These results suggest that $\operatorname{Sox} 2^{+}$glia-like cells may be a primary source of neural precursors in certain areas of adult brain. In the mammalian inner ear, recent studies have reported that the spiral ganglia of the postnatal mouse (p1-p21), as well as adult humans and guinea pigs, can produce neurospheres that proliferate and differentiate into $\beta$ tubulin $^{+}$neurons and GFAP $^{+}$glial cells with certain mitogen stimulations, thereby supporting the possibility of the presence of neural progenitor cells in postnatal and adult inner ear (Rask-Andersen et al. 2005; Boström et al. 2007; Oshima et al. 2007). In this study, we did not attempt to address whether the Sox $2^{+}$glial cells in ouabain-injured auditory nerves have the potential to generate new neurons. A significant cell loss, including glial cells, appeared in the injured auditory nerve by 30 days after ouabain exposure (Fig. 7), suggesting that 
ouabain exposure does have a direct effect on glial cells. This direct effect restricts the use of ouabaintreated mice to be employed primarily as a model to investigate the regeneration of neural cells in the adult inner ear.

In summary, our study is the first to demonstrate the expression of Sox2 in a subset of adult cochlear glial cells and the up-regulation of Sox2 expression in the injured auditory nerve. The up-regulation of Sox2 expression is associated with the increased cell proliferation observed in these auditory nerves. A subpopulation of Sox $2^{+}$glial cells express BrdU in the auditory nerve shortly after ouabain treatment, indicating that mature glial cells can change their quiescent phenotype and reenter the cell cycle in response to nerve injury. Up-regulation of Sox2 and Sox $2^{+}$glial cell proliferation are seen in the auditory nerve after ouabain treatment, suggesting that Sox2 plays an important role in regulating the injury-related activation of glial cells in the adult cochlea.

\section{ACKNOWLEDGMENTS}

The authors thank Drs. Robert D. Frisina, Xiaoxia Zhu, Vinu Jyothi, and Kelly C Harris for their assistance in ABR measurements, Mrs. Nancy M Smyth, Liya Liu, and Mr. James Nicholson for their help with histological observations, Drs. Richard A. Schmiedt, Bradley A. Schulte, Bernd Fritzsch, and three anonymous reviewers for their critical comments and invaluable discussion on this study. Grant sponsor: National Institutes of Health; grant no. DC00422 (H.L.); grant no. DC07506 (H.L.); grant no. DC00713 (B.A. S.); Office of Research \& Development, Medical Research Services, Department of Veterans Affairs (A.C.L.); American Academy of Otolaryngology-Head and Neck Surgery; grant no. CORE 130165 (L.K.).

\section{REFERENCES}

Adamson CL, Reid MA, Mo ZL, Bowne-English J, Davis RL (2002a) Firing features and potassium channel content of murine spiral ganglion neurons vary with cochlear location. J Comp Neurol 447:331-350

Adamson CL, Reid MA, Davis RL (2002b) Opposite actions of brainderived neurotrophic factor and neurotrophin-3 on firing features and ion channel composition of murine spiral ganglion neurons. J Neurosci 22(4):1385-1396

Aldskogius H, Kozlova EN (1998) Central neuron-glial and glialglial interactions following axon injury. Prog Neurobiol 55(1):126

Avilion AA, Nicolis SK, Pevny LH, Perez L, Vivian N, Lovell-Badge R (2003) Multipotent cell lineages in early mouse development depend on SOX2 function. Genes Dev 17(1):126-140

Bani-Yaghoub M, Tremblay RG, Lei JX, Zhang D, Zurakowski B, Sandhu JK, Smith B, Ribecco-Lutkiewicz M, Kennedy J, Walker PR, Sikorska M (2006) Role of Sox2 in the development of the mouse neocortex. Dev Biol 295(1):52-66
Berglund AM, Ryugo DK (1991) Neurofilament antibodies and spiral ganglion neurons of the mammalian cochlea. J Comp Neurol 306(3):393-408

Boström M, Anderson M, Lindholm D, Park KH, Schrott-Fischer A, Pfaller K, Glueckert R, Rask-Andersen H (2007) Neural network and "ganglion" formations in vitro: a video microscopy and scanning electron microscopy study on adult cultured spiral ganglion cells. Otol Neurotol 28:1109-1119

Bringmann A, Pannicke T, Grosche J, Francke M, Wiedemann P, Skatchiov SN, Osborne NN, Reichenbach A (2006) Müller cells in the healthy and diseased retina. Prog Retin Eye Res 25 (4):397-424

Buffo A, Rite I, Tripathi P, Lepier A, Colak D, Horn AP, Mori T, Göтz M (2008) Origin and progeny of reactive gliosis: a source of multipotent cells in the injured brain. Proc Natl Acad Sci USA 105:3581-3586

Clemence A, Mirsky R, Jessen KR (1989) Non-myelin-forming Schwann cells proliferate rapidly during Wallerian degeneration in the rat sciatic nerve. J Neurocytol 18(2):185-192

Corrales CE, Pan L, Li H, Liberman MC, Heller S, Edge AS (2006) Engraftment and differentiation of embryonic stem cell-derived neural progenitor cells in the cochlear nerve trunk: growth of processes into the organ of Corti. J Neurobiol 66(13):1489-1500

Dabdoub A, Puligilla C, Jones JM, Fritzsch B, Cheah KS, Pevny LH, KELLEY MW (2008) Sox2 signaling in prosensory domain specification and subsequent hair cell differentiation in the developing cochlea. Proc Natl Acad Sci USA 105(47):18396-18401

Darrow KN, Maison SF, Liberman MC (2007) Selective removal of lateral olivocochlear efferents increases vulnerability to acute acoustic injury. J Neurophysiol 97(2):1775-1785

Ding D, McFadden SL, SALVI RJ (2001) Cochlear hair cell densities and inner-ear staining techniques. In: Willott JF (ed) Handbook of mouse auditory research. CRC, New York, pp 189-204

Ferri Al, Cavallaro M, Braida D, Di Cristofano A, Canta A, Vezzan A, Ottolenghi S, Pandolfi PP, Sala M, DeBiasi S, Nicolis SK (2004) Sox2 deficiency causes neurodegeneration and impaired neurogenesis in the adult mouse brain. Development 131 (15):3805-3819

Fischer AJ, ReH TA (2001) Müller glia are a potential source of neural regeneration in the postnatal chicken retina. Nat Neurosci 4:247-252

Graham V, Khudyakov J, Ellis P, Pevny L (2003a) SOX2 functions to maintain neural progenitor identity. Neuron 39(749-65):2003

Graham V, Khudyakov J, Ellis P, Pevny L (2003b) SOX2 functions to maintain neural progenitor identity. Neuron 39(5):749-765

Guillery RW (2002) On counting and counting errors. J Comp Neurol 447(1):1-7

HAFIDI A (1998) Peripherin-like immunoreactivity in type II spiral ganglion cell body and projections. Brain Res 805(1-2):181-190

Hansen MR, Vijapurkar U, Koland JG, Green SH (2001) Reciprocal signaling between spiral ganglion neurons and Schwann cells involves neuregulin and neurotrophins. Hear Res 161(1-2):8798

Hartman BH, Basak O, Nelson BR, Taylor V, Bermingham-McDonogh O, REH TA (2009) Hes5 expression in the postnatal and adult mouse inner ear and the drug-damaged cochlea. J Assoc Res Otolaryngol 10(3):321-340

Huang LC, Thorne PR, Housley GD, Montgomery JM (2007) Spatiotemporal definition of neurite outgrowth, refinement and retraction in the developing mouse cochlea. Development 134(16):2925-2933

Hume CR, Bratt DL, Oesterle EC (2007) Expression of LHX3 and SOX2 during mouse inner ear development. Gene Expr Patterns 7(7):798-807

Hurley PA, Crook JM, Shepherd RK (2007) Schwann cells revert to non-myelinating phenotypes in the deafened rat cochlea. Eur J Neurosci 26:1813-1821 
Jagger DJ, Housley GD (2003) Membrane properties of type II spiral ganglion neurones identified in a neonatal rat cochlear slice. J Physiol 552(Pt 2):525-533

Jyothi V, Li M, Kilpatrick L, LaRue AC, Zhou D, Schulte BA, Schmiedt RA, LANG H (2010) Unmyelinated type I spiral ganglion neurons in congenic Ly5.1 mice. J Comp Neurol 518(16):3254-3271

Karl MO, Hayes S, Nelson BR, Tan K, Buckingham B, Reh TA (2008) Stimulation of neural regeneration in the mouse retina. Proc Natl Acad Sci USA 105:19508-19513

Kiernan AE, Pelling Al, Leung KK, Tang AS, Bell DM, Tease C, Lovell-Badge R, Steel KP, Cheah KS (2005) Sox2 is required for sensory organ development in the mammalian inner ear. Nature 434:1031-1035

Komitova M, EriKsson PS (2004) Sox-2 is expressed by neural progenitors and astroglia in the adult rat brain. Neurosci Lett 369(1):24-27

Komitova M, Zhu X, Serwanski DR, Nishiyama A (2005) NG2 cells are distinct from neurogenic cells in the postnatal mouse subventricular zone. J Comp Neurol 512(5):702-716 (10 Feb 2009)

Lang H, Schulte BA, Schmiedt RA (2003) Effects of chronic furosemide treatment and age on cell division in the adult gerbil inner ear. J Assoc Res Otolaryngol 4:164-175

Lang H, Schulte BA, Schmiedt RA (2005) Ouabain induces apoptotic cell death in type I spiral ganglion neurons, but not type II neurons. J Assoc Res Otolaryngol 6(1):63-74

Lang H, Schmiedt RA, Smythe N, Spicer SS, Schulte BA (2006a) Time course of glia-like cell activation and neurotrophic factor upregulation in a gerbil model of auditory neuropathy. Assoc Res Otolaryngol Abstr 27:328

Lang H, Schulte BA, Zhou D, Smythe N, Spicer SS, Schmiedt RA (2006b) Nuclear factor kappaB deficiency is associated with auditory nerve degeneration and increased noise-induced hearing loss. J Neurosci 26:3541-3550

Le N, Nagarajan R, Wang JY, Araki T, Schmidt RE, Milbrandt J (2005) Analysis of congenital hypomyelinating Egr2Lo/Lo nerves identifies Sox2 as an inhibitor of Schwann cell differentiation and myelination. Proc Natl Acad Sci USA 102:2596-2601

Leake PA, Hradek GT (1988) Cochlear pathology of long term neomycin induced deafness in cats. Hear Res 33(1):11-33

Lim DJ (1976) Ultrastructural cochlear changes following acoustic hyperstimulation and ototoxicity. Ann Otol Rhinol Laryngol 85(6 PT. 1):740-751

Mak AC, Szeto IY, Fritzsch B, Cheah KS (2009) Differential and overlapping expression pattern of SOX2 and SOX9 in inner ear development. Gene Expr Patterns 9(6):444-453

McLean WJ, Smith KA, Glowatzki E, Pүott SJ (2009) Distribution of the Na,K-ATPase alpha subunit in the rat spiral ganglion and organ of corti. J Assoc Res Otolaryngol 10(1):37-49

Morris JK, Maklad A, Hansen LA, Feng F, Sorensen C, Lee KF, Mackin WB, Fritzsch B (2006) A disorganized innervation of the inner ear persists in the absence of ErbB2. Brain Res 1091(1):186-199

Navarro-Quiroga I, Hernandez-Valdes M, Lin SL, Naegele JR (2006) Postnatal cellular contributions of the hippocampus subventricular zone to the dentate gyrus, corpus callosum, fimbria, and cerebral cortex. J Comp Neurol 497:833-845

Neves J, Kamaid A, Alsina B, Giraldez F (2007) Differential expression of Sox2 and Sox3 in neuronal and sensory progenitors of the developing inner ear of the chick. J Comp Neurol 503(4):487-500

Oesterle EC, Campbell S, Taylor RR, Forge A, Hume CR (2008) Sox2 and JAGGED1 expression in normal and drug-damaged adult mouse inner ear. J Assoc Res Otolaryngol 9:65-89

Oshima K, Grimm CM, Corrales CE, Senn P, Martinez Monedero R, GÉléoc GS, Edge A, Holt JR, Heller S (2007) Differential distribution of stem cells in the auditory and vestibular organs of the inner ear. J Assoc Res Otolaryngol 8:18-31
Pevny LH, Nicolis SK (2010) Sox2 roles in neural stem cells. Int J Biochem Cell Biol 42:421-424

Poché RA, Furuta Y, Chaboissier MC, Schedl A, Behringer RR (2008) Sox9 is expressed in mouse multipotent retinal progenitor cells and functions in Müller glial cell development. J Comp Neurol $510(3): 237-250$

Puligilla C, Dabdoub A, Brenowitz SD, Kelley MW (2010) Sox2 induces neuronal formation in the developing mammalian cochlea. J Neurosci 30:714-722

Rask-Andersen H, Boström M, Gerdin B, Kinnefors A, Nyberg G, Engstrand T, Miller JM, Lindholm D (2005) Regeneration of human auditory nerve. In vitro/in video demonstration of neural progenitor cells in adult human and guinea pig spiral ganglion. Hear Res 203:180-191

Reid MA, Flores-Otero J, Davis RL (2004) Firing patterns of type II spiral ganglion neurons in vitro. J Neurosci 24(3):733-742

Roberson DW, Rubel EW (1994) Cell division in the gerbil cochlea after acoustic trauma. Am J Otol 15:28-34

Romand MR, Romand R (1990) Development of spiral ganglion cells in mammalian cochlea. J Electron Microsc Tech 15:144-154

Romand R, Romand MR, Mulle C, Marty R (1980) Early stages of myelination in the spiral ganglion cells of the kitten during development. Acta Otolaryngol 90:391-397

RuBen RJ (1967) Development of the inner ear of the mouse: a radioautographic study of terminal mitoses. Acta Otolaryngol Suppl 220:1-44

Schmiedt RA, Okamura HO, Lang H, Schulte BA (2002) Ouabain application to the round window of the gerbil cochlea: a model of auditory neuropathy and apoptosis. J Assoc Res Otolaryngol 3:223-233

Sekerková G, Freeman D, Mugnaini E, Bartles JR (2005) Espin cytoskeletal proteins in the sensory cells of rodent taste buds. J Neurocytol 34(3-5):171-182

Shinder V, Govrin-Lippmann R, Cohen S, Belenky M, Ilin P, Fried K, Wilkinson HA, Devor M (1999) Structural basis of sympatheticsensory coupling in rat and human dorsal root ganglia following peripheral nerve injury. J Neurocytol 28(9):743-61

Silver J, Miller JH (2004) Regeneration beyond the glial scar. Nat Rev Neurosci 5(2):146-156

Sobrowicz HM, Emmerling MR (1989) Development of acetylcholinesterase-positive neuronal pathways in the cochlea of the mouse. J Neurocytol 18:209-224

SOFRONIEW MV (2005) Reactive astrocytes in neural repair and protection. Neuroscientist 11(5):400-407

Sofroniew MV (2009) Molecular dissection of reactive astrogliosis and glial scar formation. Trends Neurosci 32(12):638-647

SpoendLin H (1975) Retrograde degeneration of the cochlear nerve. Acta Otolaryngol 79(3-4):266-275

Stowe AM, Plautz EJ, Eisner-Janowicz I, Frost SB, Barbay S, Zoubina EV, Dancause N, Taylor MD, Nudo RJ (2007) VEGF protein associates to neurons in remote regions following cortical infarct. J Cereb Blood Flow Metab 27(1):76-85

Suh H, Consiglio A, Ray J, Sawai T, D'Amour KA, Gage FH (2007) In vivo fate analysis reveals the multipotent and self-renewal capacities of Sox $2^{+}$neural stem cells in the adult hippocampus. Cell Stem Cell 1(5):515-528

Takanaga H, Tsuchida-Straeten N, Nishide K, Watanabe A, Aburatani H, Kondo T (2009) Gli2 is a novel regulator of sox2 expression in telencephalic neuroepithelial cells. Stem Cells 27(1):165-174

Wang SJ, Furusho M, D'Sa C, Kuwada S, Conti L, Morest DK, BANSAL R (2009) Inactivation of fibroblast growth factor receptor signaling in myelinating glial cells results in significant loss of adult spiral ganglion neurons accompanied by age-related hearing impairment. J Neurosci Res 87(15):34283437 
Wang J, Zhang P, Wang Y, Kou Y, Zhang H, Jiang B (2010) The observation of phenotypic changes of Schwann cells after rat sciatic nerve injury. Artif Cells Blood Substit Immobil Biotechnol 38(1):24-28

Weisz C, Glowatzki E, Fuchs P (2009) The postsynaptic function of type II cochlear afferents. Nature 461(7267):1126-1129

Whitlon DS, Tieu D, Grover M, Reiliy B, Coulson MT (2009) Spontaneous association of glial cells with regrowing neurites in mixed cultures of dissociated spiral ganglia. Neuroscience 161 (1):227-235

Wise AK, Richardson R, Hardman J, Clark G, O'leary S (2005) Resprouting and survival of guinea pig cochlear neurons in response to the administration of the neurotrophins brain- derived neurotrophic factor and neurotrophin-3. J Comp Neurol 487:147-165

XIAo AY, Wei L, XIA S, Rothman S, YU SP (2002) Ionic mechanism of ouabain-induced concurrent apoptosis and necrosis in individual cultured cortical neurons. J Neurosci 22(4):1350-1362

Yamashita H, Shimogori H, Sugahara K, Takahashi M (1999) Cell proliferation in spiral ligament of mouse cochlea damaged by dihydrostreptomycin sulfate. Acta Otolaryngol 119(3):322325

Zhang P, Xue F, Zhao F, Lu H, Zhang H, Jang B (2008) The immunohistological observation of proliferation rule of Schwann cell after sciatic nerve injury in rats. Artif Cells Blood Substit Immobil Biotechnol 36:150-155 